\title{
RADIOCARBON DATING SHOWS AN EARLY APPEARANCE OF PHILISTINE MATERIAL CULTURE IN TELL ES-SAFI/GATH, PHILISTIA
}

\author{
Yotam Asscher ${ }^{1,6} \bullet$ Dan Cabanes $^{2} \bullet$ Louise A Hitchcock $^{3} \bullet$ Aren M Maeir $^{4} \cdot$ Steve Weiner $^{1} \bullet$ \\ Elisabetta Boaretto ${ }^{5,6}$
}

\begin{abstract}
The Late Bronze Age to Iron Age transition in the coastal southern Levant involves a major cultural change, which is characterized, among other things, by the appearance of Philistine pottery locally produced in styles derived from outside the Levant. This transition in the coastal southern Levant is conventionally dated to the 12th century BC, based on historical and archaeological artifacts associated with the Philistine pottery. Radiocarbon dating can provide a more precise independent absolute chronology for this transition, but dating for the period under discussion is complicated by the wiggles and relatively flat slope in the calibration curve, which significantly reduce precision. An additional complication is that the stratigraphic record below and above the transition at this site, as well as at most other sites in the region, is far from complete. We thus used a variety of microarchaeological techniques to improve our understanding of the stratigraphy, and to ensure that the locations with datable short-lived materials were only derived from primary contexts, which could be related directly to the associated material culture. The ${ }^{14} \mathrm{C}$ dates were modeled using Bayesian statistics that incorporate the stratigraphic information. Using this integrative approach, we date the appearance of the Philistine pottery in Tell es-Safi/ Gath in the 13th century BC.
\end{abstract}

\section{INTRODUCTION}

The Late Bronze Age to Iron Age transition reflects major changes in the political and social order throughout the entire eastern Mediterranean. During this transition, dominating political entities such as the Hittite and Egyptian empires were weakened and contracted, and new political orders and cultural groups appeared in the southern Levant. Among the various groups that appear during this transition are the so-called "Sea Peoples" among whom were the Philistines (Yasur-Landau 2010; Killebrew and Lehmann 2013; Hitchcock and Maeir 2014). The Philistine culture, an entangled culture comprised of both immigrants from the Aegean and surroundings, and local Levantine elements, appeared in the southern coastal plain of Canaan (Philistia) at around the time the Egyptian empire began withdrawing from Canaan, during the transition between the Late Bronze to Iron Age (Maeir et al. 2013). Synchronization of the date of the transition in Canaan with the entire eastern Mediterranean at the end of the 2nd millennium BC is based on dates of the appearance of Philistine material culture, along with other cultural elements typical of the transitional phase in the northern and southern Levant, Cyprus, and beyond. A key issue for understanding the sequence of events is determination of the exact timing of the appearance of the Philistine culture and the gradual withdrawal of the Egyptians from Canaan. We address this issue using radiocarbon dating at the Philistine site of Tell es-Safi/Gath, a multiperiod site that was a major Canaanite city during the Late Bronze Age, and a central Philistine city during the Iron Age I-II (Maeir 2012; Maeir et al. 2013).

The relative dating of this transition in southern Canaan is based mainly on the comprehensive material culture record at the end of the Egyptian domination and the appearance of the Philistine culture, in combination with available Egyptian epigraphic evidence. Epigraphic evidence of Ramses III, IV,

1. Kimmel Center for Archaeological Science, Scientific Archaeology Unit, Weizmann Institute of Science, Rehovot 76100, Israel.

2. ERAAUB, Dept. de Prehistòria, Història Antiga i Arqueologia, Universitat de Barcelona, c/ de Montalegre 6-8, Barcelona 08001, Spain. Current address: Plant Foods in Hominin Dietary Ecology Research Group, Max Planck Institute for Evolutionary Anthropology, Deutscher Platz 6, 04103 Leipzig, Germany.

3. Classics and Archaeology, University of Melbourne, Parkville 3010, Victoria, Australia.

4. The Ackerman Family Bar-Ilan University Expedition to Gath, the Martin (Szusz) Department of Land of Israel Studies and Archaeology, Bar-Ilan University, Ramat Gan 52900, Israel.

5. Weizmann Institute-Max Planck Center for Integrative Archaeology and Anthropology, Weizmann Institute of Science, Rehovot 76100, Israel.

6. D-REAMS Radiocarbon Laboratory, Scientific Archaeology Unit, Weizmann Institute of Science, Rehovot 76100, Israel. Corresponding authors. Emails: Yotam.asscher@Weizmann.ac.il; Elisabetta.Boaretto@weizmann.ac.il. 
and VI in various Canaanite sites dates the end of the Egyptian domination to the 12th century BC (e.g. Bietak 1993; Brandl 2004; Killebrew 2005:83-4). The appearance of the Philistine material culture in the southern Levant was first dated by archaeologists based on Egyptian texts to the beginning of the 20th dynasty in Egypt, at the time of Ramses III (Albright 1932; Alt 1944). This date of the appearance of the Philistines was later supported by epigraphic and iconographic evidence at the Medinet Habu temple in Egypt, in Papyrus Harris I (Killebrew 2005), and comparative dating of the initial phase of Philistine material culture, and was set to 1175 BC (Mazar 1985; Stager 1995; Cline 2014). Confusingly, this last phase of the Late Bronze Age that ended between the time of Ramses III and Ramses IV or Ramses VI (Brandl 2004; Finkelstein 2009; Finkelstein and Piasetzky 2010) is called Iron Age IA by Mazar (1990), and, alternatively, Late Bronze Age III by Ussishkin and Finkelstein (Finkelstein and Piasetzky 2011). Here, we refer to the period of the initial phase of Philistine material culture as the Iron Age, naming the ceramic phase "early Iron I."

High-precision absolute dates from Late Bronze and Iron Age layers should place the transitional relative chronology within an absolute timeframe. The most precise absolute dating method currently available, which is capable of providing subcentury precision, is ${ }^{14} \mathrm{C}$ dating. However, the Late Bronze Age to Iron Age transition occurred during a period in which the wiggles in the calibration curve form a plateau of $200 \mathrm{yr}$ (Pearson and Stuiver 1986; Reimer et al. 2013). Thus, samples dated by ${ }^{14} \mathrm{C}$ for the Late Bronze Age to Iron Age transition have large calibrated ranges, making it difficult to obtain dates of events with a precision of less than a century, irrespective of their analytical precision. Improving the resolution of dates with large calibrated ranges is commonly achieved by Bayesian statistical modeling. By sequencing the ${ }^{14} \mathrm{C}$ dates according to historical and archaeological information, the most probable calibrated date for each segment in the sequence can be modeled. Therefore, dating a sequence of strata before, during, and after the Late Bronze Age to Iron plateau in the calibration curve can increase the resolution of the absolute transition date (Manning 2006-2007).

This Bayesian modeling approach to ${ }^{14} \mathrm{C}$ dating of the Late Bronze to Iron Age transition has been applied previously to two sites in the southern Levant: Qubur el-Walaydah and Megiddo (Toffolo et al. 2014; Asscher et al. 2015). In these studies, particular attention was paid to determining whether the datable materials were unequivocally related to the archaeological context. The best contexts for high-resolution dating are those that contain short-lived datable materials found in their original depositional location or primary contexts (Boaretto 2007). Primary contexts are, defined by us, as specific locations in which the datable materials were produced in the charring process. Dating materials found in secondary contexts, not associated with the location of charring, will introduce outliers and hence will affect the chronological understanding of the site. An integrative approach is therefore needed to build a high-resolution chronology. Such an approach was previously applied at Tell-es Safi/Gath (Toffolo et al. 2012), by combining observations of macroscopic stratigraphic units with observations at the microscale (Weiner 2010) to identify appropriate contexts for ${ }^{14} \mathrm{C}$ sampling (Boaretto 2007), and by verifying that the datable context is also the charring location of the charred datable materials. Another example where a similar approach was applied is in relation to the Early Bronze Age in Megiddo (Regev et al. 2014). Sediment characterization also helps to assess the extent of bioturbation and mixing between contexts to assure that the dated material represents the age of the associated material culture.

\section{THE SITE AND ITS STRATIGRAPHY}

Tell es-Safi/Gath is situated on the border between the southern coastal plain of Israel and the Judean foothills (Figure 1). The site was settled from the Chalcolithic period until modern times with several occupation peaks, one of which is during the Iron Age. During the Late Bronze Age, the 
settlement is identified as Canaanite Gath/Gimtu, known from the el-Amarna letters, while during the Iron Age I-II ( 1200-586 BCE), the site is the location of Philistine Gath, well known from biblical and Neo-Assyrian texts (Maeir 2012). The site has been excavated regularly since 1996 by the Ackerman Family Bar-Ilan University Expedition to Gath, of the Institute of Archaeology, BarIlan University, directed by A M Maeir.

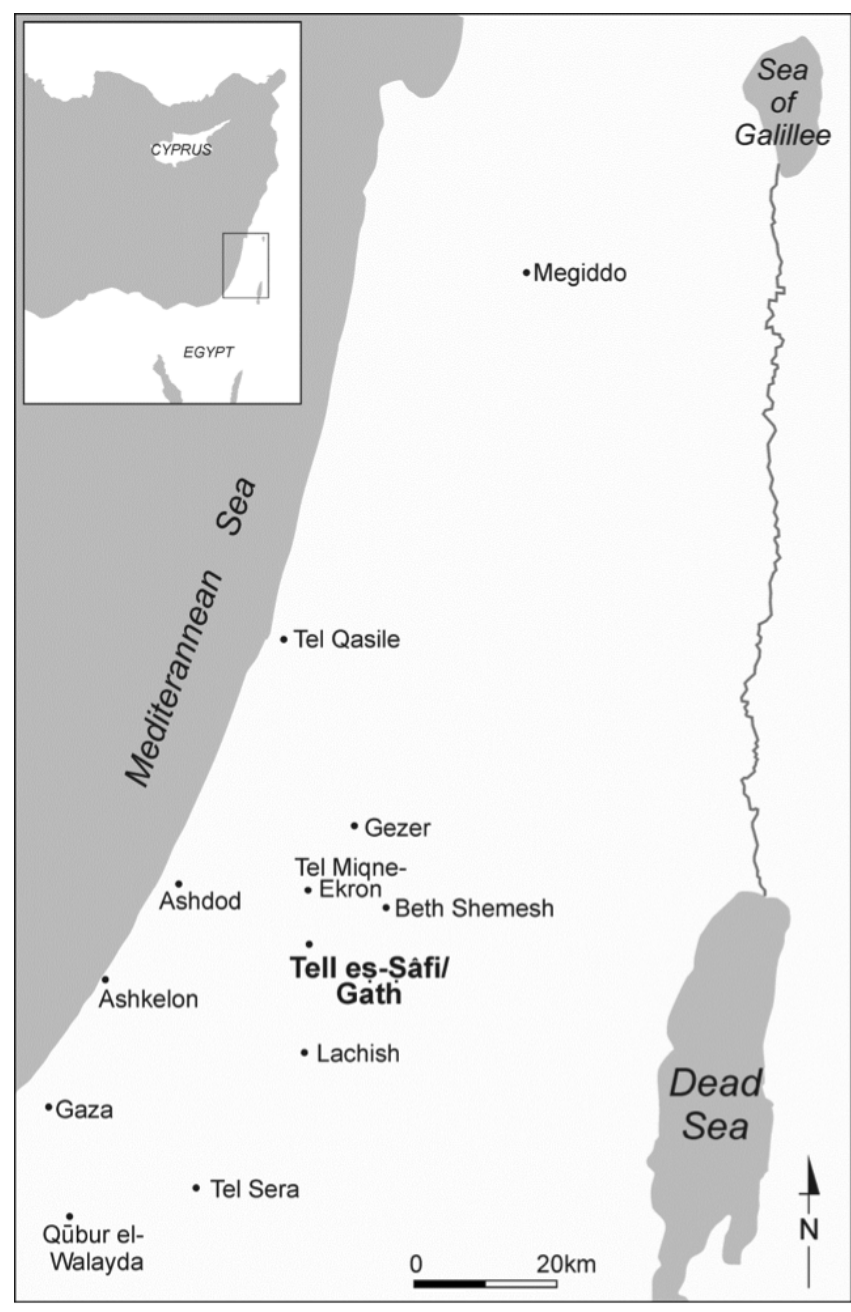

Figure 1 Map of the southern coastline of Israel. Archaeological sites from the Late Bronze and Iron Age periods are marked. Tell es-Safi/ Gath is marked in bold. Scale bar is $20 \mathrm{~km}$.

Several excavation areas were exposed on the tell (Figure S1 in the online supplementary information), showing a sequence of strata, spanning the Late Bronze Age (13th century BC) to the Iron Age IIB (late 8th century BC) (Maeir 2012; Maeir et al. 2013). Area F contains a long sequence of periods that includes the initial appearance of the Philistine material culture (Stratum F2 lower), which was ${ }^{14} \mathrm{C}$ dated (Toffolo et al. 2012). In Area P, a sequence of Late Bronze phases was found below Iron Age I phases. In Area A, the focus of this study, the Iron Age phases (late 12th to late 8th centuries BCE) are characterized by modest structures in the early Iron I, which are replaced by massive structures in the Iron IIB periods, with multiple subphases. The Late Bronze Age architecture in this area is less understood since it was exposed only in soundings and other limited exposures. Table 1 summarizes Area A stratigraphy and Figure 2 shows an aerial view as well as a N-S section of Area A. 
Table 1 Tell es-Safi/Gath, Area A stratigraphy. Numbers within the stratigraphic unit refer to the locus number unless a wall, a building, or another feature is referred to. Note that the timespans of the periods are based on relative chronologies and pottery findings, and the pottery parallels are adapted from Maeir (2012) and Mazar (1990).

\begin{tabular}{|c|c|c|c|}
\hline Stratum & Period & Stratigraphic units & Pottery parallels \\
\hline A2 & Iron IIB & Not discussed in this study & $\begin{array}{l}\text { Lachish III } \\
\text { Batash III }\end{array}$ \\
\hline A3 & $\begin{array}{l}\text { Late Iron } \\
\text { IIA }\end{array}$ & Building 23033 & $\begin{array}{l}\text { Megiddo VA-IVB } \\
\text { Miqne III } \\
\text { Qasile X } \\
\text { Ashdod X-IX } \\
\text { Lachish V-IV } \\
\text { Gezer VII-VIB } \\
\text { Aphek X6 } \\
\text { Arad XI } \\
\text { Tel Sheva V-IV }\end{array}$ \\
\hline \multirow{4}{*}{ A4 } & \multirow{4}{*}{$\begin{array}{l}\text { Early Iron } \\
\text { IIA and } \\
\text { Late Iron I }\end{array}$} & $\begin{array}{l}\text { A4 late (Wall } 33046 \text {, chalk surface } 111227 \text {, } \\
\text { hearth } 111222 \text {, sherd surface } 122035 \text {, goat } \\
\text { pit } 122041 \text {, and pavement } 122037 \text { ) }\end{array}$ & \multirow{4}{*}{$\begin{array}{l}\text { Megiddo VB } \\
\text { Miqne IVB-IVA } \\
\text { Ashdod X-IX } \\
\text { Qasile IX-VIII } \\
\text { Batash IV } \\
\text { Lachish V-IV } \\
\text { Gezer IX-VIII } \\
\text { Aphek X8-X7 } \\
\text { Izbet Sartah I } \\
\text { Arad XII } \\
\text { Tel Sheva VII-VI }\end{array}$} \\
\hline & & $\begin{array}{l}\text { A4 intermediate (foundation trench } \\
\text { 16A79D10 and Wall 53029) }\end{array}$ & \\
\hline & & $\begin{array}{l}\text { A4 middle (chalk surface 16A79D11 below } \\
\text { hearth } 111222 \text { and A3 Wall 22040) }\end{array}$ & \\
\hline & & $\begin{array}{l}\text { A4 early (Walls 33046, 43511, A15AP02, } \\
111217,63063,53035 \text {, Floor 53033, loom } \\
\text { weights surface) }\end{array}$ & \\
\hline \multirow[b]{2}{*}{ A5 } & & $\begin{array}{l}\text { A5 late (eastern part of Area } A \text { - pebble } \\
\text { layer 73007) }\end{array}$ & \multirow{2}{*}{$\begin{array}{l}\text { Megiddo VIA } \\
\text { Miqne VB-VA } \\
\text { Ashdod X-IX } \\
\text { Qasile XI-X } \\
\text { Batash V } \\
\text { Gezer XI-X } \\
\text { Aphek X10-X9 } \\
\text { Izbet Sartah II } \\
\text { Tel Sheva XI-VIII }\end{array}$} \\
\hline & Late Iron I & $\begin{array}{l}\text { A5 early (eastern part of Area A - Building } \\
73057, \text { Wall A15AP01, Hydraulic plaster } \\
\text { published in Regev et al. 2010) }\end{array}$ & \\
\hline \multirow[b]{2}{*}{ A6 } & \multirow{2}{*}{$\begin{array}{l}\text { Middle } \\
\text { Iron I }\end{array}$} & $\begin{array}{l}\text { A6 late (a room surrounded with Walls } \\
\text { A15AM07, A15AM08, A15AM09, } \\
\text { A15AL08, pebble hearth 16A90C08, and } \\
\text { surface A15AT10) }\end{array}$ & \multirow{2}{*}{$\begin{array}{l}\text { Megiddo VIB } \\
\text { Qubur el-Walaydah 1-4 } \\
\text { Miqne VIB-VC } \\
\text { Ashdod XII-XI } \\
\text { Qasile XII } \\
\text { Batash V } \\
\text { Gezer XIII-XII } \\
\text { Aphek X10-X9 } \\
\text { Izbet Sartah III }\end{array}$} \\
\hline & & $\begin{array}{l}\text { A6 middle (stratified sediments with no } \\
\text { architecture, rubbish deposits } 111209 \text {, } \\
\text { 132012, 132018, refuse pit } 132004 \text { ) }\end{array}$ & \\
\hline
\end{tabular}


Table 1 Continued

\begin{tabular}{|c|c|c|c|}
\hline Stratum & Period & Stratigraphic units & Pottery parallels \\
\hline A7 & $\begin{array}{l}\text { Late Bronze } \\
\text { IIB }\end{array}$ & $\begin{array}{l}\text { Decayed mudbricks, cooking installation } \\
\text { A15AS07, A15AL03 (pebble surface) (lim- } \\
\text { ited exposure in soundings) }\end{array}$ & $\begin{array}{l}\text { Qubur el-Walaydah 1-5 } \\
\text { Ashdod XIV } \\
\text { Hazor XIII } \\
\text { Tel Yin'am VIB } \\
\text { Beth Sean VII } \\
\text { Megiddo VIIB } \\
\text { Aphek X12 } \\
\text { Gezer XV } \\
\text { Beth Shemesh IV } \\
\text { Batash VIA } \\
\text { Miqne VIIIA } \\
\text { Lachish VII } \\
\text { Tel Sera X }\end{array}$ \\
\hline A8 & EB III & $\begin{array}{l}\text { Decayed mudbricks } \\
\text { (limited exposure in soundings) }\end{array}$ & N/A \\
\hline
\end{tabular}

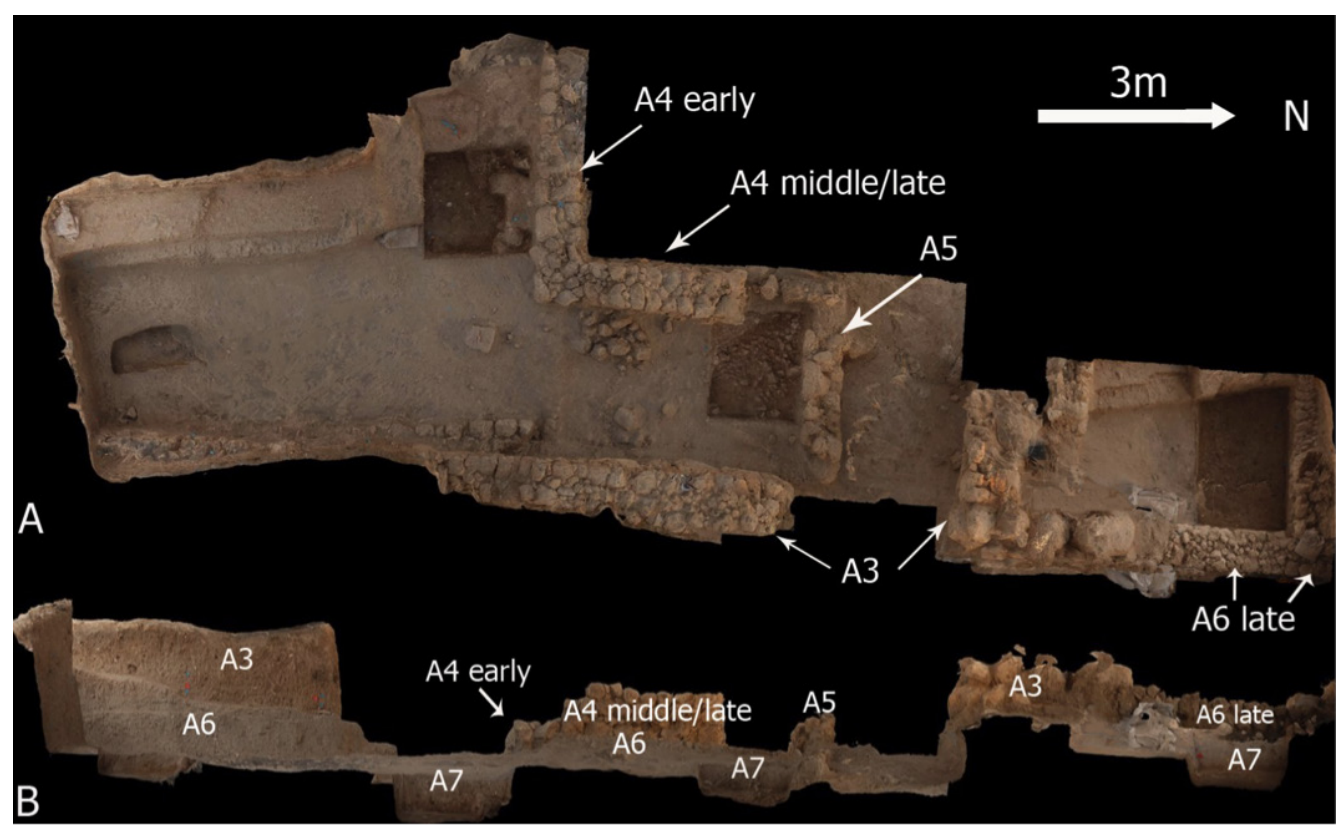

Figure 2 A 3D view of the part of Area A from which the samples for dating were obtained. Scale bar is $3 \mathrm{~m}$. (A) Planar view, with labels identifying walls from different periods. (B) A north-south cross-section showing the different strata. Note that only the soundings exposed Late Bronze layers (A7). These images were obtained using Agisoft PhotoScan Professional Edition v1.0.4 (see Materials and Methods).

The Early Bronze phase (Stratum A8) and the Late Bronze phase (Stratum A7) were exposed mainly in $1 \times 1.5 \mathrm{~m}$ soundings along the north-south axis of Area A (Figure 2). Above the Late Bronze phase, layers containing Iron I material culture were found (Strata A6, A5, and A4). The stratigraphy of Area A varies along the north-south axis, and in the southern part, Strata A4 and A5 are not found and Stratum A3 directly overlies two phases (early and late) of Stratum A6. In the north of 
Area A, architecture from Strata A5 and A4 include a series of floors and architectural features that cut one another, and cut into Stratum A6. Philistine architectural features found in Strata A6, A5, and A4 include pebble hearth cooking installations (Gur-Arieh et al. 2012), hydraulic plaster that was found from the beginning of the Late Bronze Age in the Aegean world (Regev et al. 2010), and a "temple" that is similar to a temple found at Tel Qasile, Stratum X (Maeir 2012), as well as fragmentary domestic architecture (Hitchcock et al. 2015).

\section{MATERIAL CULTURE AND ITS ASSOCIATION WITH HISTORICAL DATES}

At Tell es-Safi/Gath, a single Late Bronze Age phase was exposed in three soundings in Area A (Stratum A7 in Figure 2). Complete vessels were not found, but local Late Bronze pottery and Cypriot imports such as Cypriot White Slip II and Base-Ring Ware, as well as Aegean imports, such as Late Helladic IIIB and Late Helladic III A2, were found. These imports are from the periods of the Late Bronze IIA and IIB (14th and 13th centuries). These imports were also found in Stratum A6, together with Iron I materials.

The Iron Age phase in Area A was exposed over $180 \mathrm{~m}^{2}$. The phase extends through four strata (A2A6) and large pottery assemblages were found. To distinguish between imported Mycenaean IIIC vessels and locally produced Mycenaean IIIC style pottery, it has been suggested to call the locally produced Mycenaean IIIC style (Monochrome style) "Philistine 1," while the Philistine Bichrome style is now often labeled "Philistine 2" (Dothan et al. 2006). Philistine 3 (Debased) pottery, namely red slipped pottery and Black-on-Red Phoenician ware (Maeir 2012), is also present.

In Area A, material culture from Stratum A6 includes Philistine 1 and Philistine 2 pottery that associates Stratum A6 with the middle Iron I period (12th-11th century BC based on relative chronology). Stratum A5 contains Iron I local pottery, Philistine 2, and sporadic Philistine 3 pottery, associating it to Late Iron I (11th-10th century BC). Material culture from Stratum A4 included local pottery, Philistine 3, red-slipped and hand burnished bowls, associating it with late Iron I and early Iron IIA (10th-9th century BC). Stratum A4 is associated with different phases in different parts of Area A (Maeir 2012:302). In the southern part of Area A (south of Wall 43511), Stratum A4 is associated with the late Iron I period. In the middle part of Area A (north of Wall 43511), Stratum A4 is associated with the early Iron IIA period. In this study, the contexts for dating associated with Stratum A4 were adjacent to Wall 43511, and the period ascribed was based on associated material culture. Early Iron IIA ceramics were not found in any of the loci and contexts that were used for dating in this study. Therefore, Stratum A4 is associated in this study with the late Iron I period. Stratum A3 included a destruction layer found in the upper and lower city, which was associated with Hazael, King of Aram Damascus' military campaign in the southern Levant (Maeir 2012). The destruction layer was dated by ${ }^{14} \mathrm{C}$ (RTK 4409) to 833-801 at $1 \sigma$ deviation (Sharon et al. 2007), which agrees with a suggested dating of $\sim 830$ BCE based on historical analysis (Maeir 2012). Material culture from Stratum A3 includes Late Philistine Decorated Ware (LPDW), local Iron Age cooking and storage jars, and sporadic Black-on-Red Phoenician ware, which date this layer to late Iron IIA, of the mid-to-late 9th century BCE.

In Area F, Philistine 1 pottery was found on a surface from Stratum F2 lower (associated with the Early Iron I). Stratum F2 lower is considered earlier than Stratum A6 (based on relative chronology, since Stratum A6 contains Philistine 2 pottery). In Area P, Late Bronze cooking pots were found in Stratum P2, associating this phase with the Late Bronze IIB (contemporaneous with Stratum A7).

Figure 3 shows representative indicative pottery from the Late Bronze Age and the Iron Age in Area A. Late Bronze Age IIB pottery, associated with Stratum A7, includes decorated Cypriote 
White Slip "Milk Bowl" fragments. Early Iron I pottery, associated with Stratum A6, shows Philistine 1 and Philistine 2 pottery (descriptions of styles are noted in the online supplementary information). Based on sherds alone, it is difficult to determine the stratigraphy of the area.

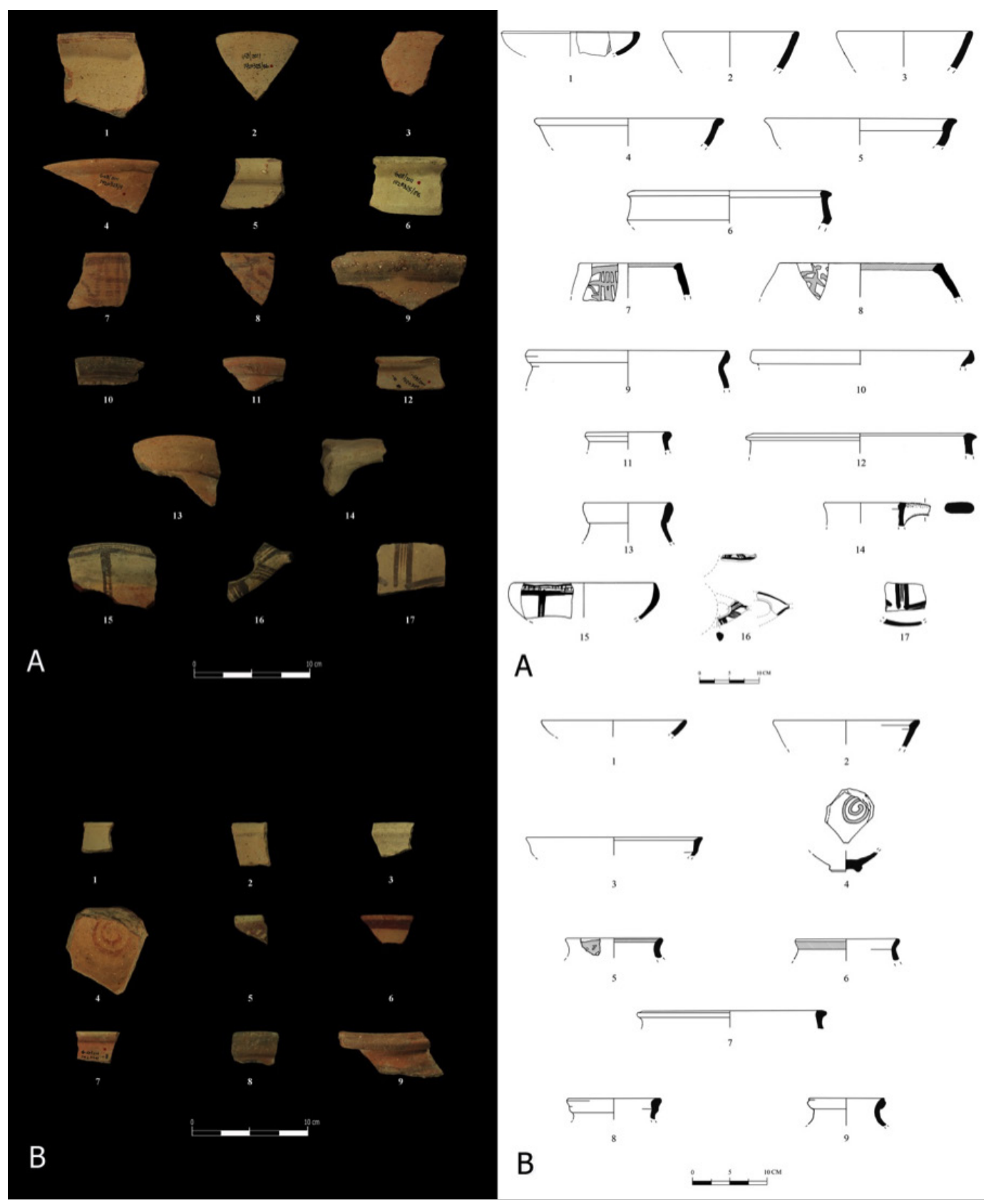

Figure 3 Indicative pottery types found in Loci 142206 and 142201 in Area A. (A) Photograph of the finds in basket 1420325 in Locus 142206 , adjacent to their drawings. Note that Cypriote imports were found in the basket, associating it to the Late Bronze IIB period. Scale bar is $10 \mathrm{~cm}$. (B) A photograph of the finds in basket 1420261 in Locus 142201, adjacent to their drawings. Scale bar is $10 \mathrm{~cm}$. 


\section{MATERIALS AND METHODS \\ Choice of Samples for Dating}

Only charred seeds were selected for this study to avoid the old-wood effect. A key issue is that the contexts in which the charred seeds were found should ideally be the original location where the seeds were charred. After determining that indeed the context is the original charring location of the charred remains, careful attention was paid to the association with the macro- and microstratigraphy of the context. The macrostratigraphy was best described using a combination of visual observations, mineralogical components in the sediments, and material culture findings, while the microstratigraphy description was mainly based on observation of thin sections under the microscope, and determinations of the mineral constituents of each layer or structural entity. Particular attention was paid to the presence of ash, phytoliths, heated clays, aragonite produced at high temperatures, microcharcoal, and phosphates as these components can be used to determine whether the datable charred remains were found at the location where they were charred (primary context). Secondary contexts were also dated when clusters of seeds were found in a clear stratified sequence. The assumption is that the clusters were deposited at the location where found, and thus can be associated to the material culture.

\section{Fourier Transform Infrared (FTIR) Spectroscopy}

FTIR was used both on-site and off-site. A few grams of archaeological sediments from key contexts and control samples from the geological surroundings were collected. Part of the sample was homogenized in an agate mortar and approximately $0.2 \mathrm{mg}$ were ground to a fine powder and then mixed with $\sim 20 \mathrm{mg}$ of $\mathrm{KBr}$ (FTIR-grade). Samples were then pressed into a 7-mm pellet using a hand press (PIKE Technologies) or a manual hydraulic press (Specac). Infrared spectra were obtained on-site using a Nicolet iS-5 spectrometer at $4 \mathrm{~cm}^{-1}$ resolution, and off-site using a Nicolet 380 spectrometer at $4 \mathrm{~cm}^{-1}$ resolution.

\section{Micromorphology}

Samples were collected from key contexts using the conventional method of wrapping sediments with Plaster of Paris and consolidating using resin following Courty et al. (1989). Briefly, the blocks were then dried in an oven at $50^{\circ} \mathrm{C}$ for 3 days and then impregnated using a 9:1 mixture of polyester resin and acetone. Precut $2 \times 3$ inch sample slices were thinned to $30 \mu \mathrm{m}$ thickness (prepared by Quality Thin Sections, Tucson, Arizona). The prepared thin sections $(n=4)$ were studied using polarizing light microscopes (Nikon Labophot2-LOP and Nikon Eclipse 50iPOL) at various magnifications $(20 \times, 40 \times, 100 \times, 200 \times$, and $400 \times)$. Micromorphological descriptions employed the terminology of Bullock et al. (1985) and Stoops (2003). For more details, see Friesem et al. (2011).

\section{Phytolith Concentrations}

Phytolith concentrations were determined following Katz et al. (2010). Briefly, sediment samples $(n=75)$ were homogenized and 20-30 $\mathrm{mg}$ (accurately weighed) were placed in a $0.5-\mathrm{mL}$ Eppendorf tube. Then, $50 \mu \mathrm{L}$ of $6 \mathrm{~N} \mathrm{HCl}$ were added to dissolve the carbonates. After carbonate dissolution, $450 \mu \mathrm{L}$ of sodium polytungstate $(2.4 \mathrm{~g} / \mathrm{mL}$ density) were added and then vortexed, followed by sonication for $20 \mathrm{~min}$ (Cole-Parmer). Samples were then centrifuged at $5000 \mathrm{rpm}$ for $5 \mathrm{~min}$. The supernatant was transferred to another tube, vortexed, and $50 \mu \mathrm{L}$ of the solution were placed on a slide and covered with a cover-glass. Phytoliths were counted at $200 \times$ magnification using a Nikon Eclipse 50iPOL microscope following the method described in Katz et al. (2010).

\section{Phytolith Refractive Index Determination}

The phytolith refractive index (RI) was determined following the protocol of Elbaum et al. (2003). Briefly, about $0.5 \mathrm{mg}$ of purified phytoliths were placed on a slide, and a liquid with a known re- 
fractive index $(\mathrm{RI}=1.44)$ was added. The RI of a single phytolith was measured using the Becke line (Head 1962). The measurement was performed at 400× magnification using a Nikon Eclipse 50iPOL microscope.

\section{Radiocarbon Dating}

Datable materials were collected either by hand when found in datable contexts on site, or sediments from datable contexts were dry-sieved (aluminum sieve, $1 \mathrm{~mm}$ ). Charred seeds were picked out from the material that did not pass through the sieve. Seed samples $(n=14)$ were monitored using FTIR to determine whether the seeds were contaminated by clay before the removal of carbon contaminants (Rebollo et al. 2008). Pretreatment of the charred remains to remove all contaminants prior to the measurement was performed following the published protocols (Yizhaq et al. 2005; Rebollo et al. 2008; Boaretto 2009). The purity of the recovered charcoal was tested again using FTIR to determine if the material remaining contains clay minerals (in which case they were not dated) (Yizhaq et al. 2005). Samples were oxidized in vacuum with cuprum oxide $(\mathrm{CuO})$ at $900^{\circ} \mathrm{C}$. Pretreatment efficiency and percent carbon in the samples showed a good charcoal preservation. The sample was then graphitized in the presence of hydrogen and cobalt at $700{ }^{\circ} \mathrm{C} .{ }^{14} \mathrm{C}$ determinations were made using an accelerator mass spectrometer (AMS) in Rehovot, Israel (the AMS is named D-DREAMS, and it is a 1.5SDH Pelletron, National Electrostatics Corp). Modeling was carried out using OxCal v 4.2.3 (Bronk Ramsey 1995, 2009).

\section{D Modeling of Area A}

A 3-dimensional (3D) recording of Area A was carried out during the excavation season of 2013 following Olson et al. (2013). The 3D reconstruction was done by taking around 150 pictures of the area from multiple angles, using digital cameras. The photographs were then uploaded into the software Agisoft PhotoScan Professional Edition v1.0.4, and areas that were out of focus or with no interest were masked out. The workflow process of the software was to align photographs (with high accuracy), build a dense cloud of points (at high quality), build a mesh from the cloud points (using high polygon count), and finally texture (using average blending mode). Finally, 11 coordinate points that were measured using a total station (electronic theodolite) were incorporated into the model, and the agreement of displacement between the total station and the reconstructed points was within $5 \mathrm{~cm}$.

\section{RESULTS}

Five locations within Area A (Figure 4), one location from Area P, and one location from Area F were chosen for dating the Late Bronze to Iron Age transition because they contained well-defined pottery assemblages from the relevant periods. Also, their datable materials were short-lived samples found mainly in contexts that contained evidence for primary deposition.

\section{Area A Sediments}

Below Stratum A5, a gray-colored fine-grained sediment layer is present, which contrasts in color to the overlying brown-colored sediments. Both the brown and gray sediments contain similar bulk compositions (calcite, clay, and quartz), but the gray sediments also contain charred organic material and abundant phytoliths compared to the overlying Stratum A3 brown sediments (Figure 5). We therefore designated Stratum A6 as a gray phytolith-rich layer.

In the southern part of Area A (Excavation Squares 90C and 89D in Figure 4), Strata A4 and A5 are not found, and Stratum A3 directly overlies the gray layer (Stratum A6). In the north of Area A, architecture from Strata A4 and A5 directly overlies the gray layer. 


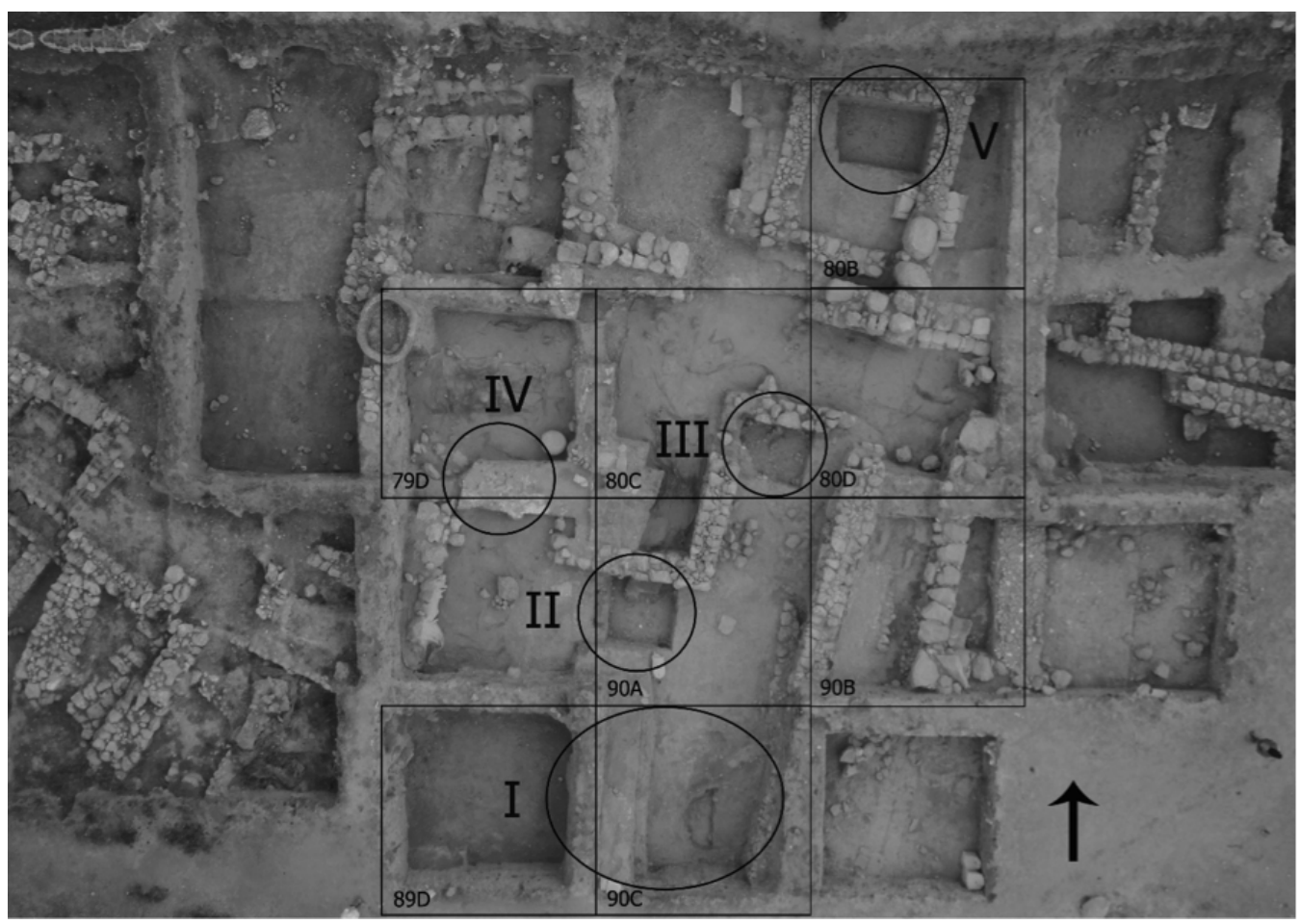

Figure 4 Aerial view of Area A in Tell es-Safi/Gath. The five locations investigated in detail are shown in circles; squares are $5 \times 5 \mathrm{~m}$.

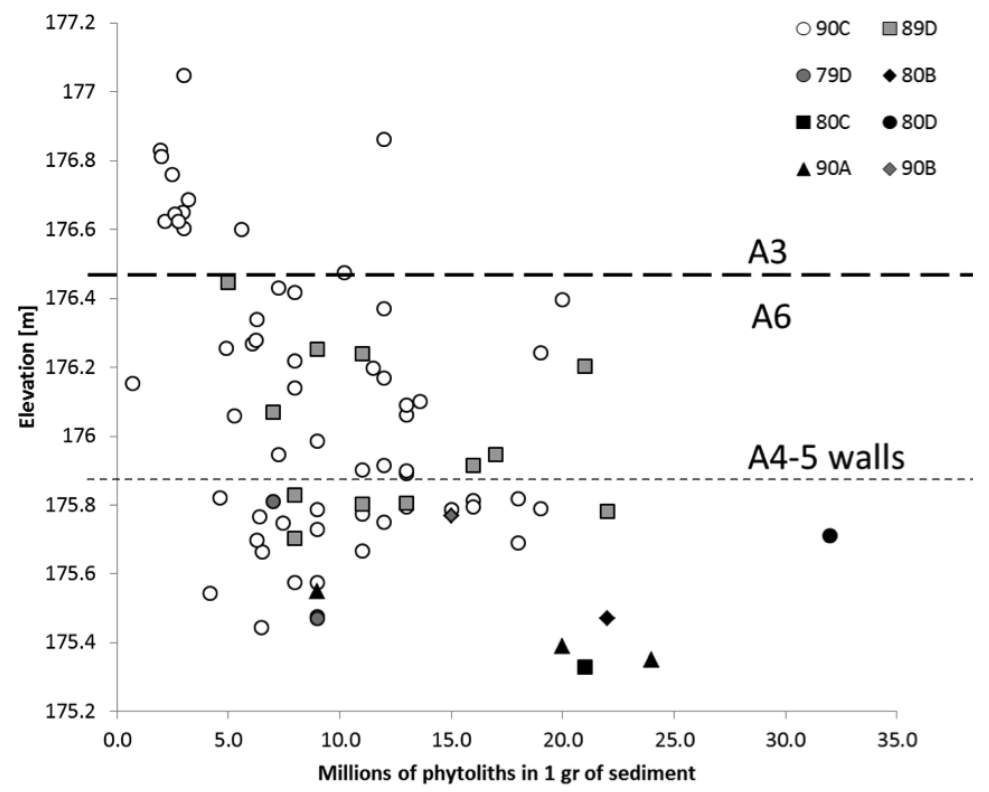

Figure 5 Phytolith concentrations in sediments of Strata A3 and A6. Samples of Stratum A3 were collected only from Square 90C, and the bold dashed line is located at the elevation that separates Strata A3 and A6 in Square 90C. Samples from Strata A4 and A5 are missing in Square 90C. A thin dotted line represents the lowest elevation of Strata A4 and A5 walls that cut into Stratum A6 in the northern part of Area A. Samples from Stratum A6 were collected from the baulks in Squares 90C and 89D and below Strata A4 and A5 walls in Squares 79D, 80B, 80C, 80D, 90A, and 90B. Namdar et al. (2011) report similar phytolith concentrations in Stratum A3, except at one specific location. 


\section{Locality I}

Two different episodes of cultural occupation (Iron II and Iron I) were found in the stratified sediments of Square 90C and in the baulk between Squares 90C and 89D. Stratum A3 contains Late Iron IIA pottery (late 9th century BCE) buried in brown sediments between 177.4-176.4 m (all heights are above sea level). Stratum A6 is below and in contact with Stratum A3. A pebble hearth (16A90C08; elevation 176.44-176.39 m) was found at the contact between Strata A6 and A3, suggesting a surface of occupation. Below the hearth, stratified gray phytolith-rich sediments with no architecture (Figure 6) contained small amounts of Iron I pottery between 176.4-175.2 m, including Philistine 1 and Philistine 2 pottery. The intermediate strata (A4-A5) are represented only by few pottery shards without any architectural features (Hitchcock et al. 2015). Figure 6 shows the western baulk of Square 90C, where a sequence of sediments shows the Iron I gray layer below the Late Iron IIA brown layer, and the pebble hearth at the boundary between the two layers.

Two micromorphological blocks were taken from locations in Stratum A6 (Figure 6). In general, the blocks show that the sediments are highly bioturbated. There are, however, locations with microlaminations of phytoliths (inset Figure 6). Spherulite-rich sediments are also present (white arrows in Figure 6), indicating that these sediments contained a large component of animal dung, which is most likely also the source of the phytoliths. The refractive index of phytoliths extracted from these sediments was higher than RI 1.44, suggesting exposure to elevated temperatures (Elbaum et al. 2003). Therefore, the gray sediment (Stratum A6) is a stratified accumulation of burnt dung.

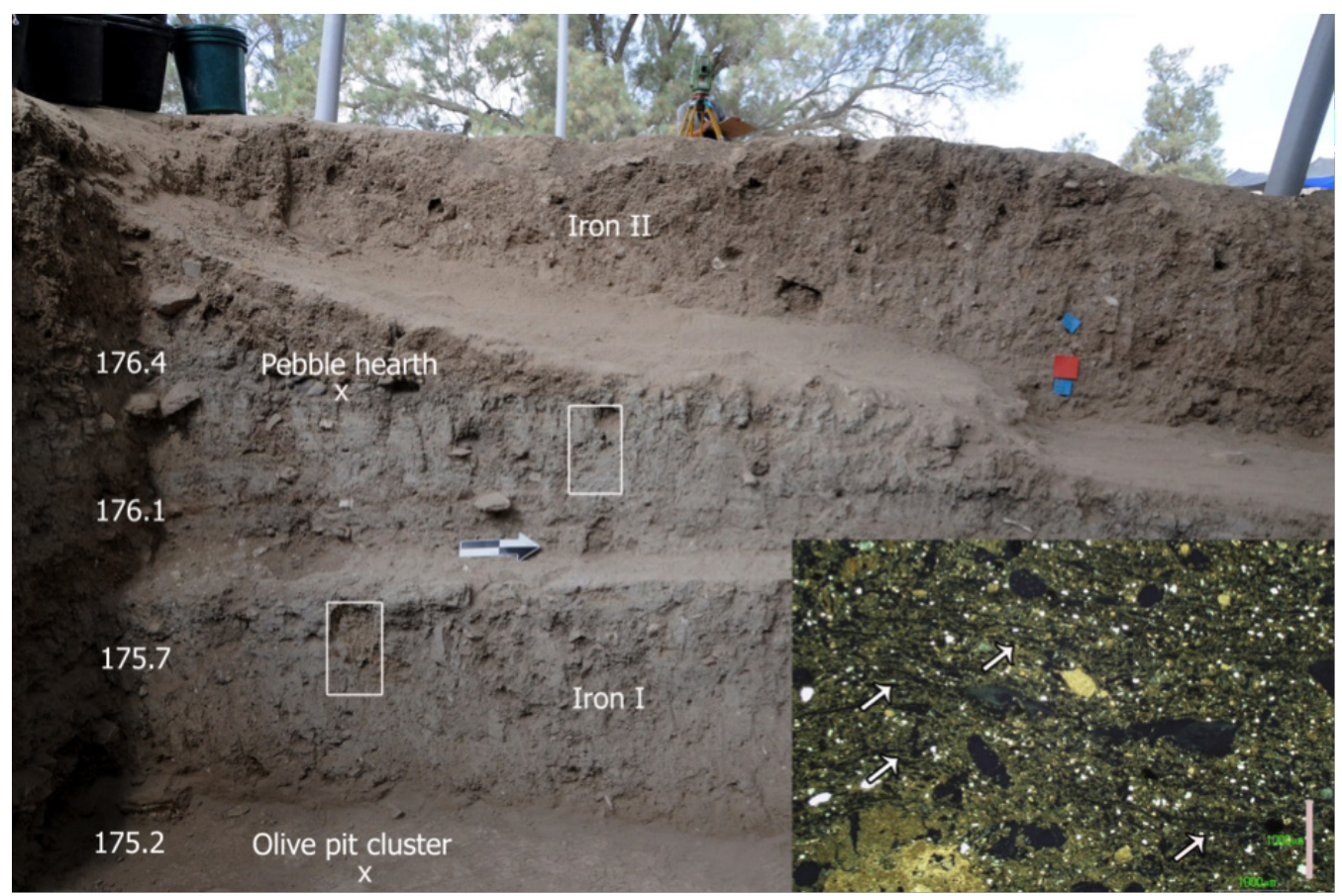

Figure 6 The western section in Square 90C (Locality I). The sediments show course approximately horizontal layering. The Stratum A3 Iron II (brown) layer directly overlies the Stratum A6 Iron I gray phytolith-rich layer, with a pebble hearth at the interface between the two layers. X symbols denote datable sample locations. One cluster of seeds was found in a pebble hearth at the top of the gray layer, and another in homogeneous sediments at the bottom of the gray layer at an elevation of around $175.2 \mathrm{~m}$. Scale bar is $20 \mathrm{~cm}$. The white squares show the location of blocks sampled for micromorphology. The inset shows representative sediments from the blocks under cross-polarized light. The white arrows point to laminated phytolith and spherulite-rich layers in plain polarized light; scale bar $=1000 \mu \mathrm{m}$. 
Datable materials were collected from Stratum A6. A cluster of olive pits was found in the pebble hearth (Figure 6; Locus 16A90C08; $176.4 \mathrm{~m}$ ). A second cluster of olive pits was found in homogenized sediments with no direct indication of burning, but at the bottom of the gray layer, which is mostly composed of burnt dung, at $175.2 \mathrm{~m}$. Other less well-defined datable assemblages were collected at elevations $175.8 \mathrm{~m}, 175.81-175.75 \mathrm{~m}$, and $175.72-175.51 \mathrm{~m}$ within the gray layer in Square 90C. These datable assemblages (including charred seeds) were not found in their production site, and were either collected as an assemblage by sieving sediments from the gray phytolith-rich layer or were directly identified as clusters while excavating. The gray layer is an invaluable marker horizon, as it underlies all the Iron Age architecture and overlies the LB strata. The gray layer also does contain some pottery that presumably was deposited together with the burnt dung. This pottery assemblage can therefore be related to the dates obtained.

\section{Locality II}

Locality II is sequence of sediments with the youngest layer having been deposited after Wall 43511 was constructed, and the oldest at the bottom of a sounding made in Square 90A adjacent to an Iron I or early Iron IIA wall (Wall 43511 in Figure 7). The sequence from top to bottom of Locality II begins with a pebble hearth (Locus 111222; elevation 176.15-176.09 m) containing charred grape seeds, which was associated with late Stratum A4. The pebble hearth and a series of related features (Hitchcock et al. 2015) were found above a chalk plaster surface (Locus $111227 ; 176.05 \mathrm{~m}$ ) that covered parts of Wall $43511(176.0-175.8 \mathrm{~m})$. The base of Wall 43511 was above the Iron I gray phytolith-rich layer (Stratum A6; 175.8-175.6 m). The gray layer was on top of a stratified sequence of sediments that contained different types of pottery in each stratum. Below the gray sediments, a large well-de-

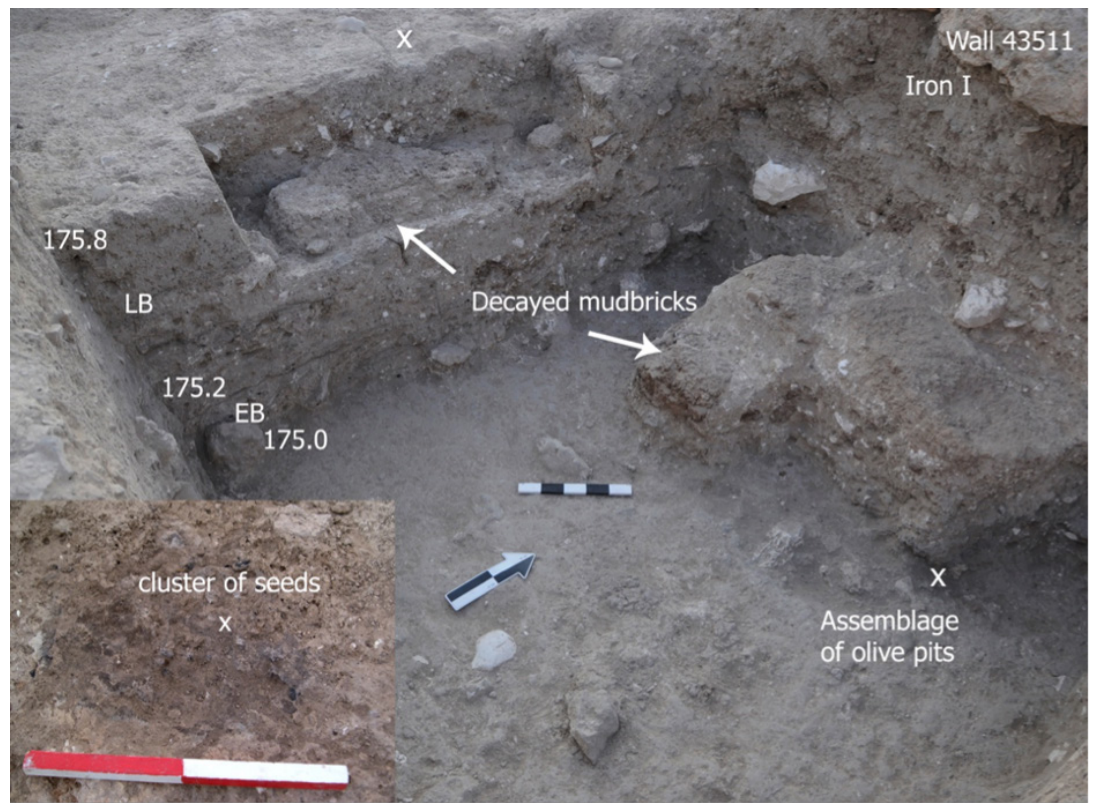

Figure 7 Locality II. An adjacent sounding in Square 90A, but beneath Iron Age Wall 43511. The periods are shown according to elevations. The gray layer was found with Iron I material under the Iron Age wall, and on top of a decayed mud bricks layer that contained Late Bronze Age pottery. Inset shows the general location of a cluster of seeds found burnt in situ in a feature at the top of the Late Bronze Age layer excavated in the 2012 season under Wall 43511. Scale bar $20 \mathrm{~cm}$. The Late Bronze layer was found on top of a layer containing an Early Bronze age III pottery and an ashy context. An assemblage of olive pits was found in the ash context within the Early Bronze Age layer below a mudbrick. Contexts for dating are marked with X. Arrow scale bar $20 \mathrm{~cm}$. 
fined burnt feature was found that contained 30 olive pits (Locus A15AS07; 176.65-176.50 m). The burnt feature was above darker brown sediments with decayed mudbricks containing Late Bronze Age pottery with scattered bones and charcoal pieces (Stratum A7; 175.6-175.2 m). Below the Late Bronze Age brown sediments was a layer with Early Bronze Age sherds (Stratum A8; 175.2-175.0 m).

The datable samples from Locality II include the grape seeds from the pebble hearth (Locus 111222: elevation $176.15 \mathrm{~m}$ ), a cluster of olive pits from a burnt Late Bronze Age feature (Locus A15AS07: $175.65 \mathrm{~m}$ ), and an assemblage of olive pits at the bottom of the Early Bronze age layer, all confined to a well-defined ash layer (Locus 16A90A09: $175.10 \mathrm{~m}$ ).

\section{Locality III}

Locality III is a sounding in Square 80C adjacent to an Iron Age wall (Wall A15AP01 in Figure 8). The Iron Age wall (elevation 176.0-175.6 m) is on top of a stratified sequence of sediments that contained different types of pottery: Iron I (175.6-175.3 m), Late Bronze (175.3-175.2 m), and Early Bronze (175.2-175.0 m) ages. The gray layer (Stratum A6) was found under Wall A15AP01 containing Iron I pottery and high phytolith concentrations. Below the gray layer, a pebble surface with phytoliths (Locus 16A80C03; $175.35 \mathrm{~m}$ ) was found associated with Late Bronze Age material. A fragment of plaster, identified as hydraulic plaster using infrared spectroscopy following the characterization of Regev et al. (2010), was found on top of the pebble surface. The hydraulic plaster was tentatively dated to the late Iron I based on the associated ceramics (Stratum A5) in a different location in Area A (Regev et al. 2010). However, the pebble surface was found at the bottom of the gray layer fill (Stratum A6), and on top of the pebble surface that is stratigraphically pre-Stratum A6. Datable material included an assemblage of olive pits from within the phytolith surface. The datable

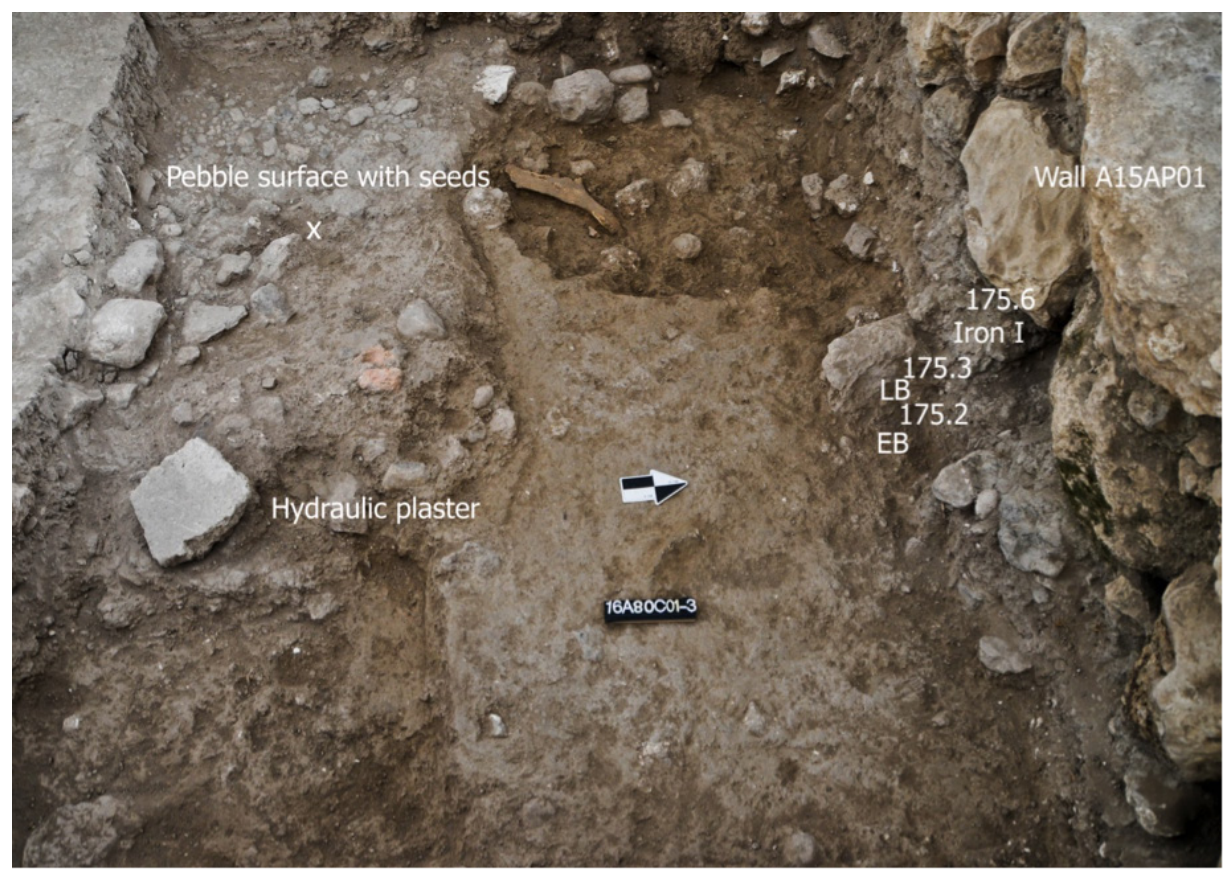

Figure 8 Locality III. The sounding in Square 80C adjacent to a late Iron I wall (A15AP01). Periods are shown according to elevations. The gray phytolith-rich sediments were found below Wall A15AP01 containing Iron I pottery. A pebble surface was found below the gray layer associated with Late Bronze Age pottery, a hydraulic plaster fragment, and phytoliths surface. Datable seeds were collected from within the phytolith surface. The context for dating is marked with X. Scale bar arrow is $10 \mathrm{~cm}$. 
material should provide an absolute date of the time of surface-use, which is associated to Late Bronze pottery (Stratum A7). It will also date the terminus post quem for the hydraulic plaster.

\section{Locality IV}

Locality IV contains clay-rich sediments found under an Iron Age wall (Stratum A3), associated with Stratum A4 in Square 79D. In the clay rich sediments, a burnt feature containing ash (Locus 16A79D06; elevation 176.3-176.1 $\mathrm{m}$ in Figure 9) was found. The ashy context contained a cluster of olive pits ( $n=120$ seeds), which was found associated with a chalk surface (Locus 16A79D11; 176.1-176.5 m), associated with Stratum A4. Stratum A5 was missing from this location and the chalk surface was found above the gray layer (Stratum A6). The sediments associated with the cluster contained clay components that were exposed to temperatures above $400^{\circ} \mathrm{C}$ (Eliyahu-Behar et al. 2012), indicating the cluster was found in its original production site. Pottery findings associated with this context are from Iron I.

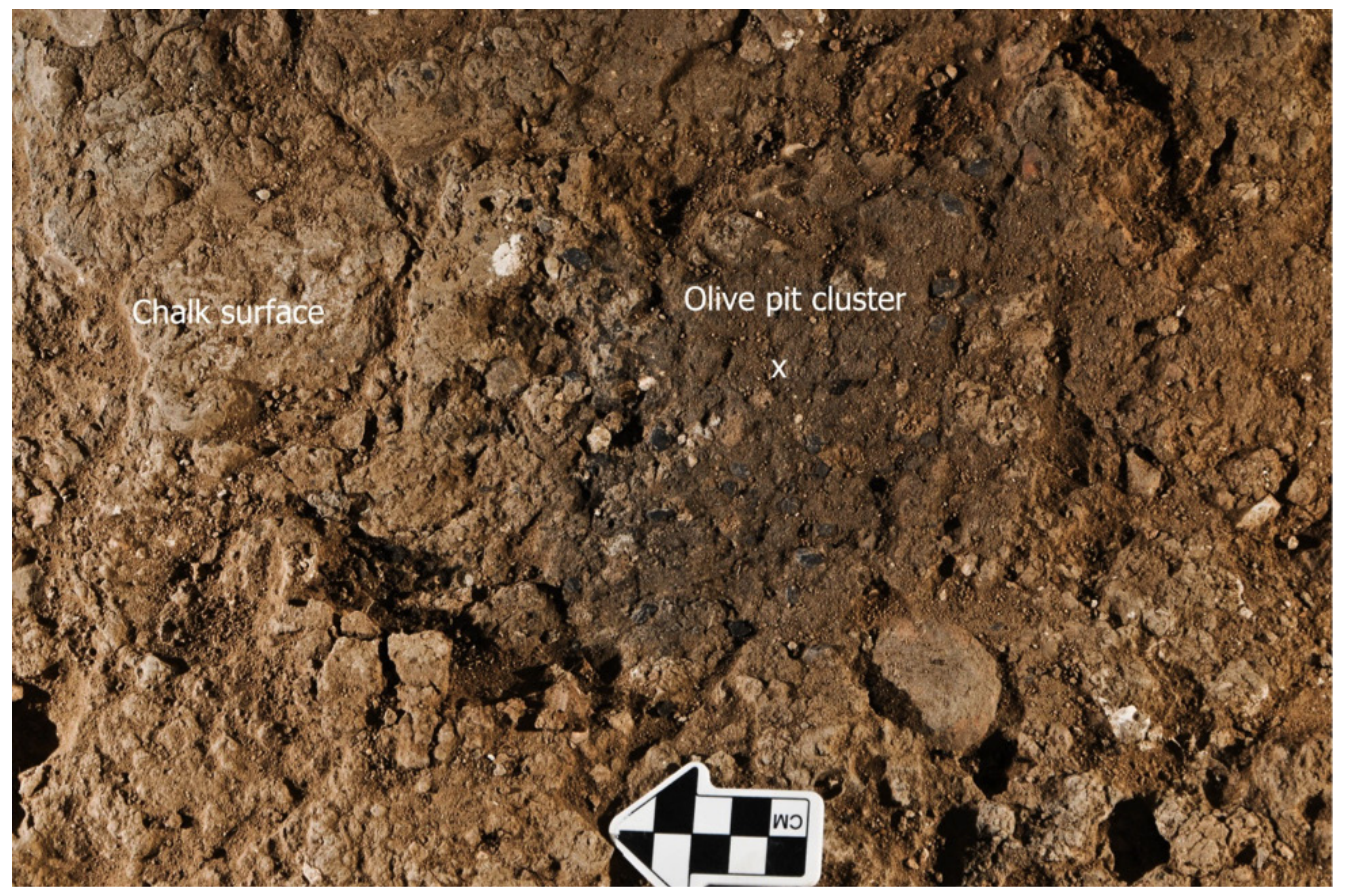

Figure 9 Locality IV. Clay-rich sediments found on top of a chalk surface and under an Iron Age wall in Square 79D. An olive pit cluster (marked with an $\mathrm{X} ; n=120$ seeds) was found in the sediments that were exposed to temperatures above $400^{\circ} \mathrm{C}$. Pottery findings are associated with an Iron I context. Scale bar is $5 \mathrm{~cm}$.

\section{Locality V}

Locality V is a sounding in Square 80B adjacent to an Iron Age wall (Wall A15AM08; elevation $176.2-176.0 \mathrm{~m}$ in Figure 10). The Iron Age wall was on top a stratified sequence of sediments that contained Late Bronze Age pottery (176.0-174.6 m). The upper Iron Age layer contained gray sediments rich in phytoliths (Figure 5); however, the ceramics did not include the Philistine 1 and Philistine 2 assemblages that were found in Stratum A6 (the gray phytolith-rich sediments). Datable materials were collected by sieving the gray layer found below Wall A15AM08. Brown sediments with Late Bronze Age pottery are present beneath the gray layer, and at the bottom of the sounding a surface associated with Late Bronze Age pottery contained an assemblage of charred seeds. The seeds were handpicked from the surface. 


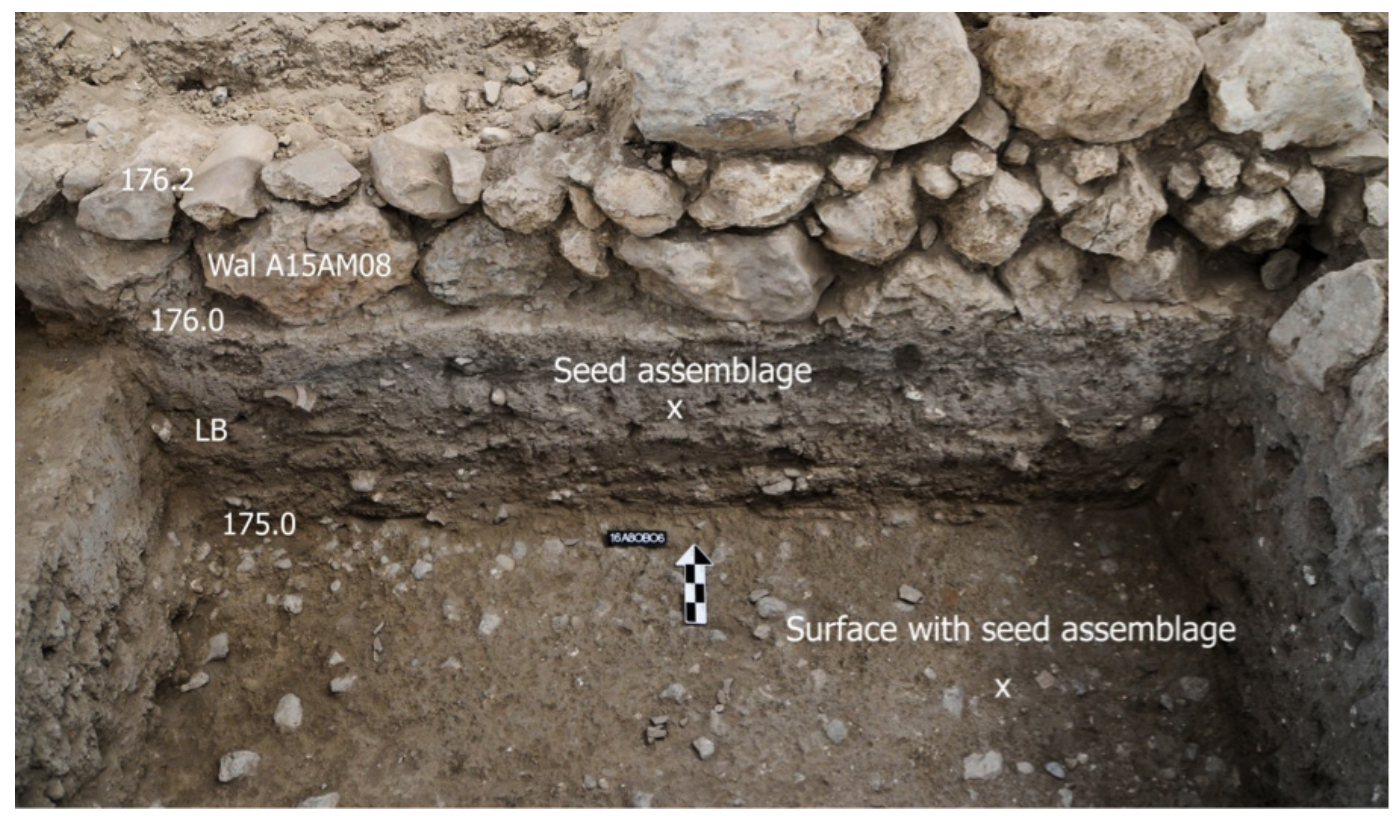

Figure 10 Locality V. A sounding in Square 80B adjacent to an Iron Age wall (Wall A15AM08). The periods are shown according to elevations. The gray layer found under the wall contained Iron I pottery, with an assemblage of seeds. Below the gray layer, at the bottom of the Late Bronze Age layer, a surface was found with Late Bronze Age pottery and an assemblage of seeds. Datable contexts are marked with X. Arrow scale is $20 \mathrm{~cm}$.

\section{Area $\mathbf{P}$}

Area $\mathrm{P}$ is located on a slope about $50 \mathrm{~m}$ west of Area A. The stratigraphy of Area P includes three strata associated with the Bronze and Iron Ages. Stratum P1 is associated with Iron Age I and Iron Age II. Stratum P2 is associated with the Late Bronze Age, and Stratum P3 is associated with the Early Bronze Age. Three rooms, containing Iron Age sediments overlying Late Bronze Age sediments, were the locality of study in Area P. In Square 41C, an Iron Age wall (Wall 108018; elevation 183.4-183.0 m) was found on top of a stratified sequence of sediments with several white phytolith-rich surfaces, that contained two types of pottery: Iron I (183.0-182.85 m) and Late Bronze Age (182.85-182.70 m). The sequence of phytolith surfaces sealed the sediments below from disturbances caused by slope erosion. In the southern corner of Square 41C, next to Wall 108016, Late Bronze Age pottery was exposed on top of a phytolith surface. In the north part of Square 41C, associated with the same phytolith surface, a cluster of olive pits was found in situ with evidence of sediments exposed to elevated temperatures above $400^{\circ} \mathrm{C}$ (Eliyahu-Behar et al. 2012). Figure 11 shows the Late Bronze Age pottery and an olive pit cluster associated with the phytolith layer. A block for micromorphology was taken. The microstatigraphy of the olive pit cluster context shows fine laminated phytoliths in sediments above the charred sediments of the olive pit cluster, and evidence for sediments exposed to heat were found below the charred layer. Below the burnt sediments, another layer with laminated phytoliths was found, showing well-defined microstratigraphy.

Table S2 in the online supplementary information lists the 12 dated samples from Area A, the two samples from Area P, and the three samples from Area F. The unmodeled dates are in the range of the expected periods according to the pottery assemblages; no outliers were recorded. The dates are organized according to the stratigraphy within each locality. 


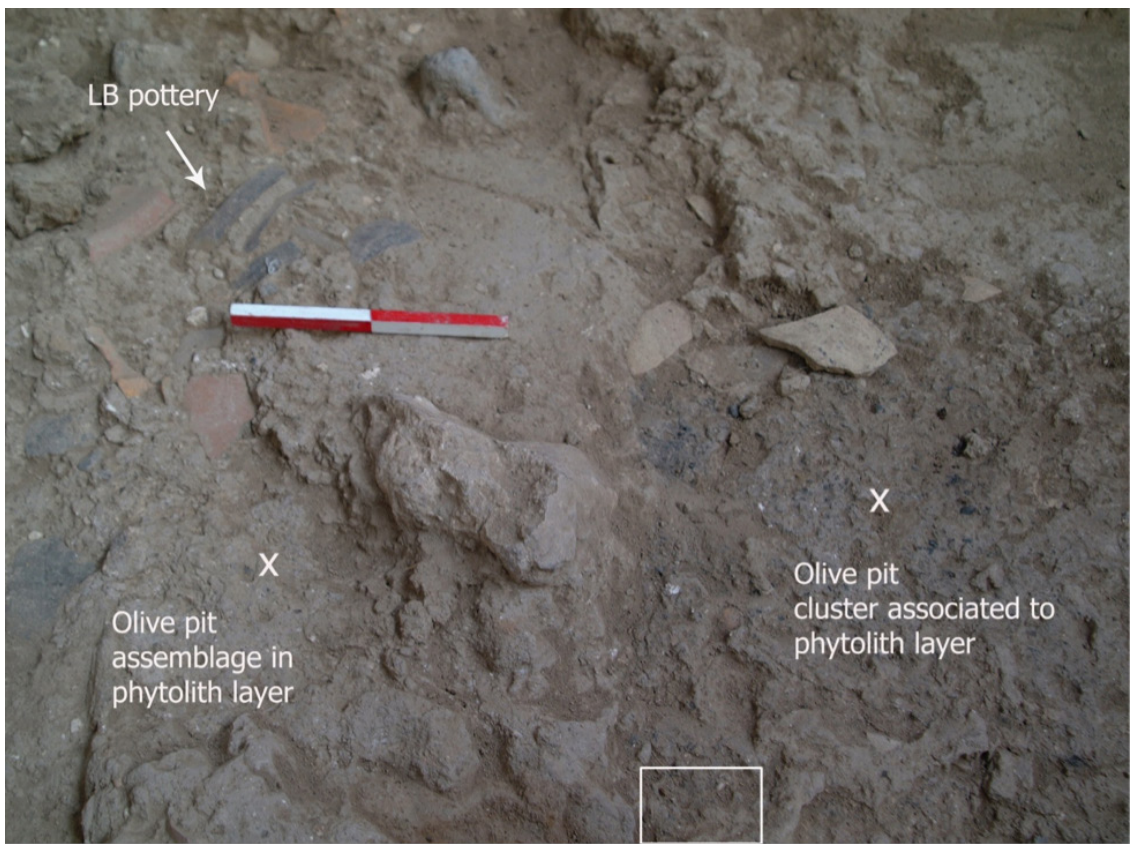

Figure 11 Area P, a room in Square 41C. Contexts for dating were found associated with a phytolith layer containing Late Bronze Age pottery. The context for dating was sealed below a sequence of phytolith surfaces. A cluster of olive pits was found in situ, and an olive pit assemblage was collected within the phytolith layer associated with the burnt feature. Datable contexts are marked with X. Scale is $20 \mathrm{~cm}$. A white rectangle represents the location of the micromorphology block.

\section{DISCUSSION}

Figure 12 is a schematic illustration of the stratigraphy of Localities I-V in Area A, from which most of the datable samples were collected. The detailed stratigraphy shows a complex accumulation of five stratigraphic phases in a meter and a half (Strata A3-A7: between elevations 176.5-175 m) that span the Late Bronze Age to the late Iron IIA, based on pottery typology. Most of the stratigraphic units with datable contexts can be linked physically to form a well-defined geostratigraphic sequence of Late Bronze and Iron Age layers from Localities I, II, III, and IV. Contexts from Locality V in Area A, Area P, and Area F (not shown in Figure 12) had no clear stratigraphic relations with Localities I to IV in Area A and were assumed to be contemporaneous based on associated material culture assemblages. We therefore first model the dates from Localities I to IV as a geostratigraphic sequence, and determine the Late Bronze to early Iron Age transition date. As a second step, we incorporate the dates from Area A, Locality V, Area P, and Area F.

\section{Geostratigraphic Model of Area A: Localities I-IV}

The geostratigraphic model described in the following commences with the levels below the Late Bronze Age phase, associated with Stratum A8 (RTD 7098), namely an Early Bronze Age phase. Following the Early Bronze Age phase, two contexts for dating were sequenced, which are associated with Stratum A7 (RTD 7098, 6711) and were located below the gray sediments. Since these contexts had no physical connection, they were considered as an unordered group of events (in the OxCal software, this is executed by the command "phase"). Above Stratum A7, a layer of gray sediments rich in phytoliths (Stratum A6) was found in Localities I, II, and III (but not in Locality IV). Datable contexts from Stratum A6 were found only in Locality I, and are sequenced from early to 
late as follows: RTD 7095, (Phase: 6579, 6580, 6581), 6983 (Figure 12). Stratum A5 contained no datable materials. Stratum A4 is subdivided into two subphases: the earliest sample (RTD 7200) was associated with Stratum A4 middle, and above that was a sample from a hearth that was associated with Stratum A4 late (RTK 5940).

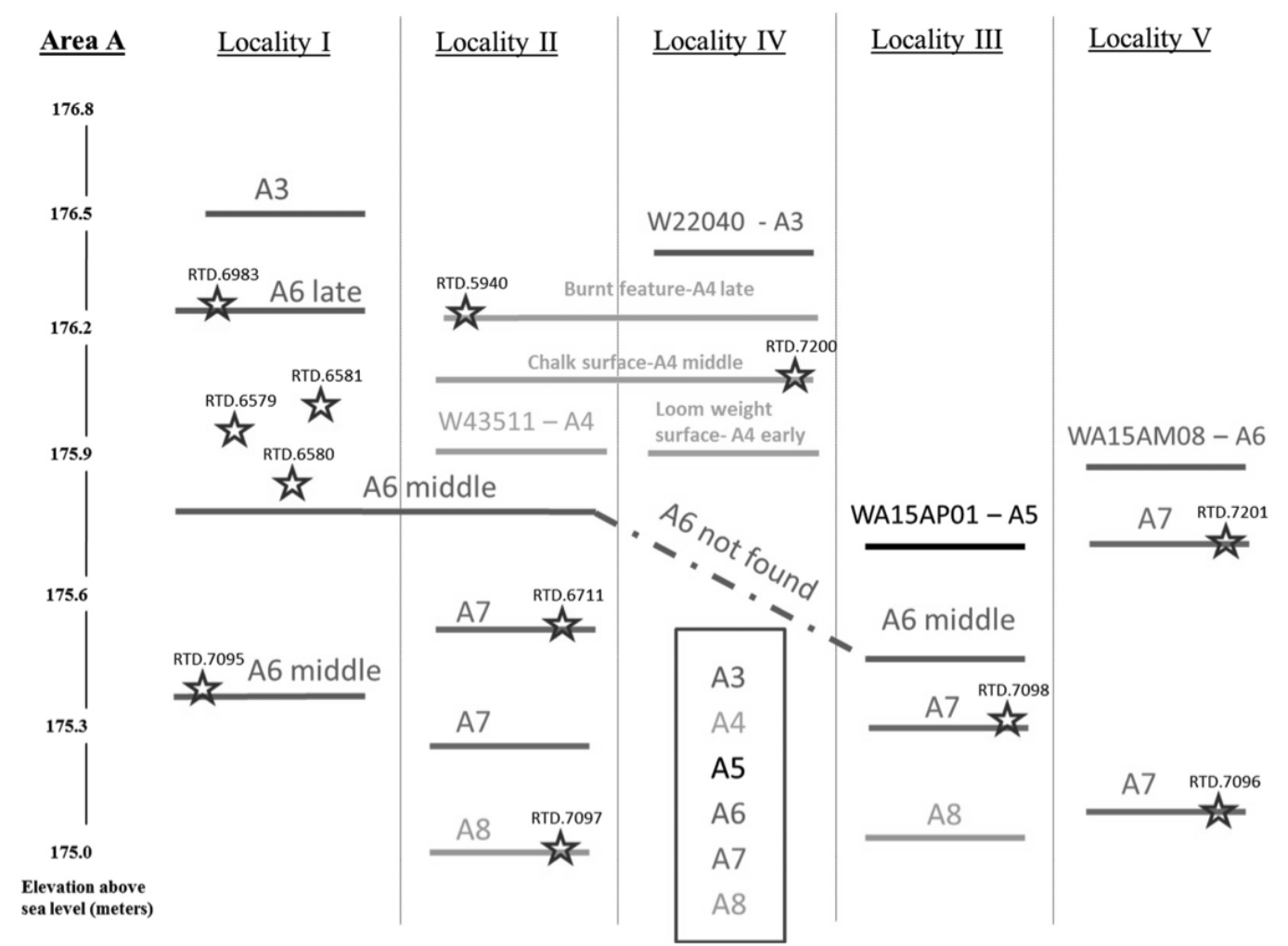

Figure 12 Schematic illustration of the stratigraphy from Area A. The strata are arranged according to elevation above sea level and according to the studied localities. The dated contexts are marked with stars and strata are coded according to grayscale intensity. Note that none of the dated contexts could be associated with Stratum A5 as part of a geostratigraphic sequence.

The absence of datable samples from Stratum A5 is represented as a time gap in the model. Gaps of different duration were tested using OxCal software. Figure 13 shows that the time gap that best accounts for the lack of dates from Stratum A5 is between 20-30 yr in the model (agreement of $155 \%$ ). A gap of less than $30 \mathrm{yr}$ is considered insignificant due to the resolution of a single ${ }^{14} \mathrm{C}$ measurement and the calibration during this period. Therefore, we chose to model the dates with a gap of $30 \mathrm{yr}$ (agreement of 155\%).

Figure 14 shows the sequence of dates for Localities I-IV modeled using Bayesian statistics, according to geostratigraphy with a simulated gap of $30 \mathrm{yr}$ to represent Stratum A5, calibrated using OxCal v 4.2.3. The transition between Strata A7 (associated with Late Bronze Age pottery) and Stratum A6 (associated with middle Iron I) is between 1245-1160 BC at $1 \sigma$ confidence level (model agreement of $155 \%)$.

A weakness of the model from Localities I-IV is that these localities do not include a layer with only Philistine 1 pottery, which is associated with the early Iron I phase in the coastal southern Levant. At the sites of Ashdod, Ashkelon, and Ekron, the early phase of Philistine 1 pottery is considered 


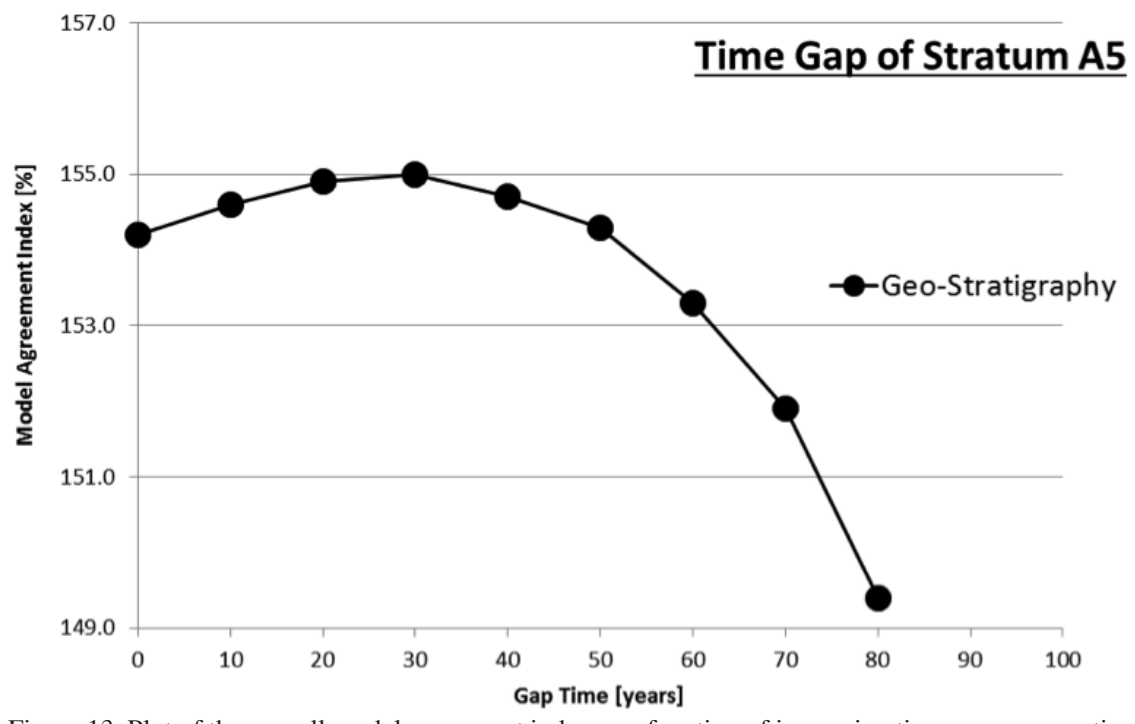

Figure 13 Plot of the overall model agreement index as a function of increasing time gap representing Stratum A5. The model agreement index is the highest for $20-30 \mathrm{yr}$ (155\% agreement) in the geostratigraphic model.

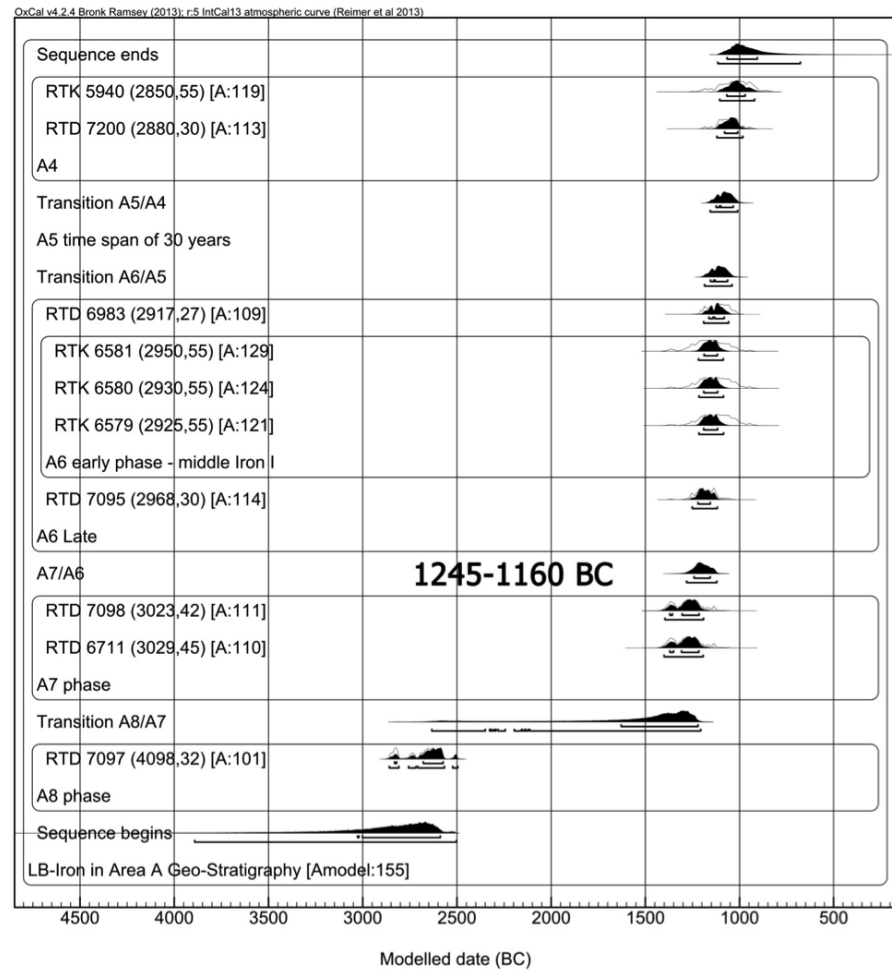

Figure 14 Calibrated and modeled dates from Area A, Localities I-IV in Tell es$\mathrm{Safi} / \mathrm{Gath}$. Dates are arranged in a sequence from the earliest Stratum A7 to the latest Stratum A4. Dates are presented with their lab number, age before calibration, precision (in parentheses), and their agreement index (in square brackets). The modeled date of the Late Bronze Age (Stratum A7) to Iron Age (Stratum A6) transition is between $1245-1160 \mathrm{BC}$ at $1 \sigma$ confidence level.

as the phase in which the Philistine culture first appeared in Philistia (Dothan and Freedman 1967; Dothan 1971; Dothan and Porath 1982, 1993; Dothan and Ben-Shlomo 2005; Dothan et al. 2006; Master et al. 2011). At Tell es-Safi/Gath, the early Iron I phase, containing only Philistine 1 pottery, was found in Area F; we therefore assume it is present in Area A, but has not been exposed to date. 
To account for the absence of the earliest Iron I phase, a gap was introduced into the model using the "interval" command in OxCal between Strata A7 and A6 to represent the period timespan, following the same procedure as the modeled gap of Stratum A5 (mentioned above).

Figure 15 shows the model agreement index and the modeled transition date for a changing gap span between $0-130 \mathrm{yr}$ for the early Iron I phase. The range of agreement is between 140-153\% (plotted by open circles). The high agreement is a result of high tolerance of the model to a change in the time gap, and this is a consequence of the wide range of probabilities of a single ${ }^{14} \mathrm{C}$ determination (due to the calibration curve). A gap of less than $30 \mathrm{yr}$ is considered insignificant due to the resolution of the ${ }^{14} \mathrm{C}$ measurement and the calibration uncertainty (the time gap was monitored down to $0 \mathrm{yr}$, to understand the overall trend). Figure 15 also shows the modeled transition date for a changing gap span (plotted by black lines), between Stratum A7 (associated with Late Bronze IIB) and the early Iron I phase. The highest model agreement is for a gap range of $50 \mathrm{yr}$ of the early Iron I phase (agreement of $155 \%$ ), which models the date of the Late Bronze to Iron Age transition to between 1270-1190 BC at $1 \sigma$ confidence level. We note that even if the timespan of the gap is halved, the transition timespan remains almost the same, during the second half of the 13th century.

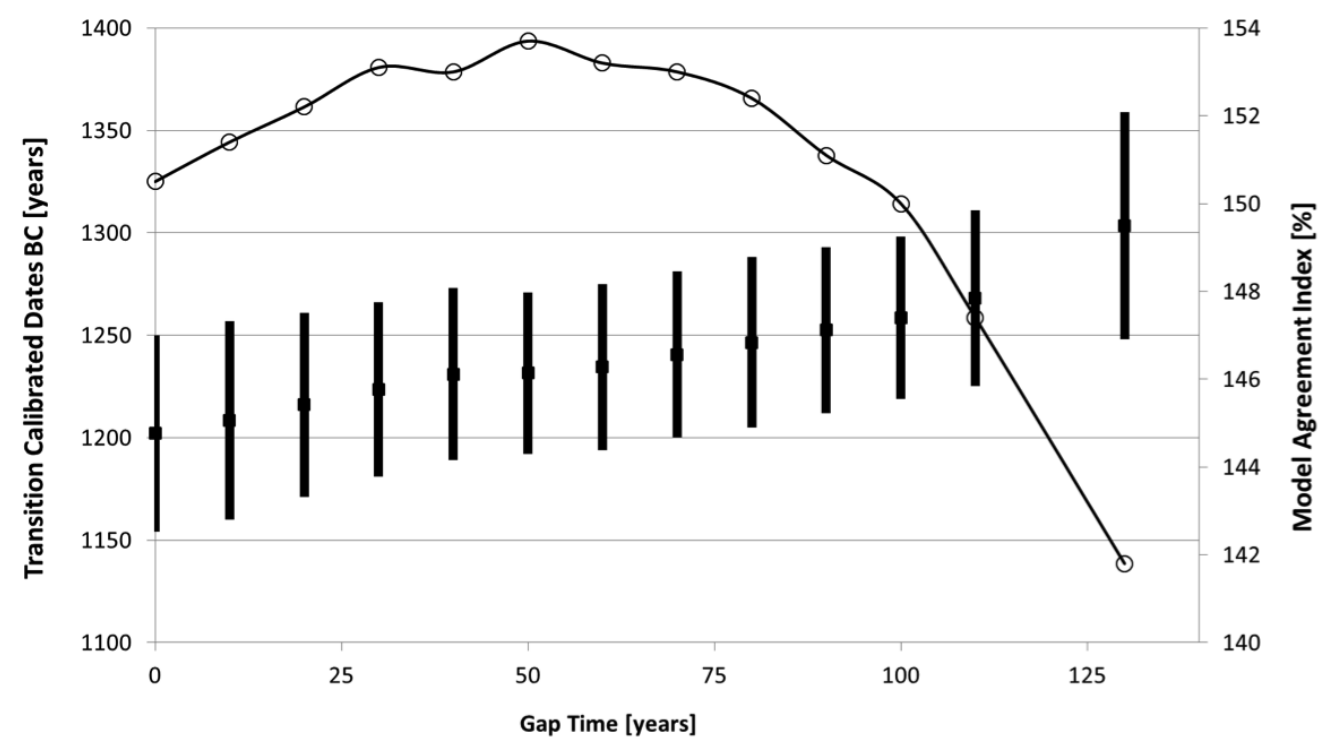

Figure 15 Plot of the overall model agreement index, and modeled transition date as a function of increasing gap time of the early Iron I phase. The model agreement index is marked by open circles (associated with the right axis), with the highest for a gap of $50 \mathrm{yr}(155 \%$ agreement $)$ in the geostratigraphic model. Modeled transition date ranges are shown as black lines with the modeled date as a black dot. The transition date for a gap of $50 \mathrm{yr}$ is between $1270-1190 \mathrm{BC}$ at $1 \sigma$ confidence level.

Figure 16 shows the sequence of dates for Localities I-IV modeled using Bayesian statistics, according to geostratigraphy with a simulated gap of $50 \mathrm{yr}$, calibrated using OxCal v 4.2.3. The transition between Strata A7 (associated with Late Bronze Age pottery) and the simulated gap (associated with early Iron I) is between 1270-1190 BC at $1 \sigma$ confidence level (model agreement of 155\%).

A weakness of this model is that the minimal exposure of the Late Bronze IIB phase [in soundings and sporadic architectural features, see more in Gur Arieh et al. (2012)] makes it difficult to understand the stratigraphic connections between the different Late Bronze contexts. Therefore, the Late Bronze phase did not have inner geostratigraphic relations, which reduces the number of ${ }^{14} \mathrm{C}$ dates used in the model to two. This affects the accuracy and precision of the Late Bronze phase date. 


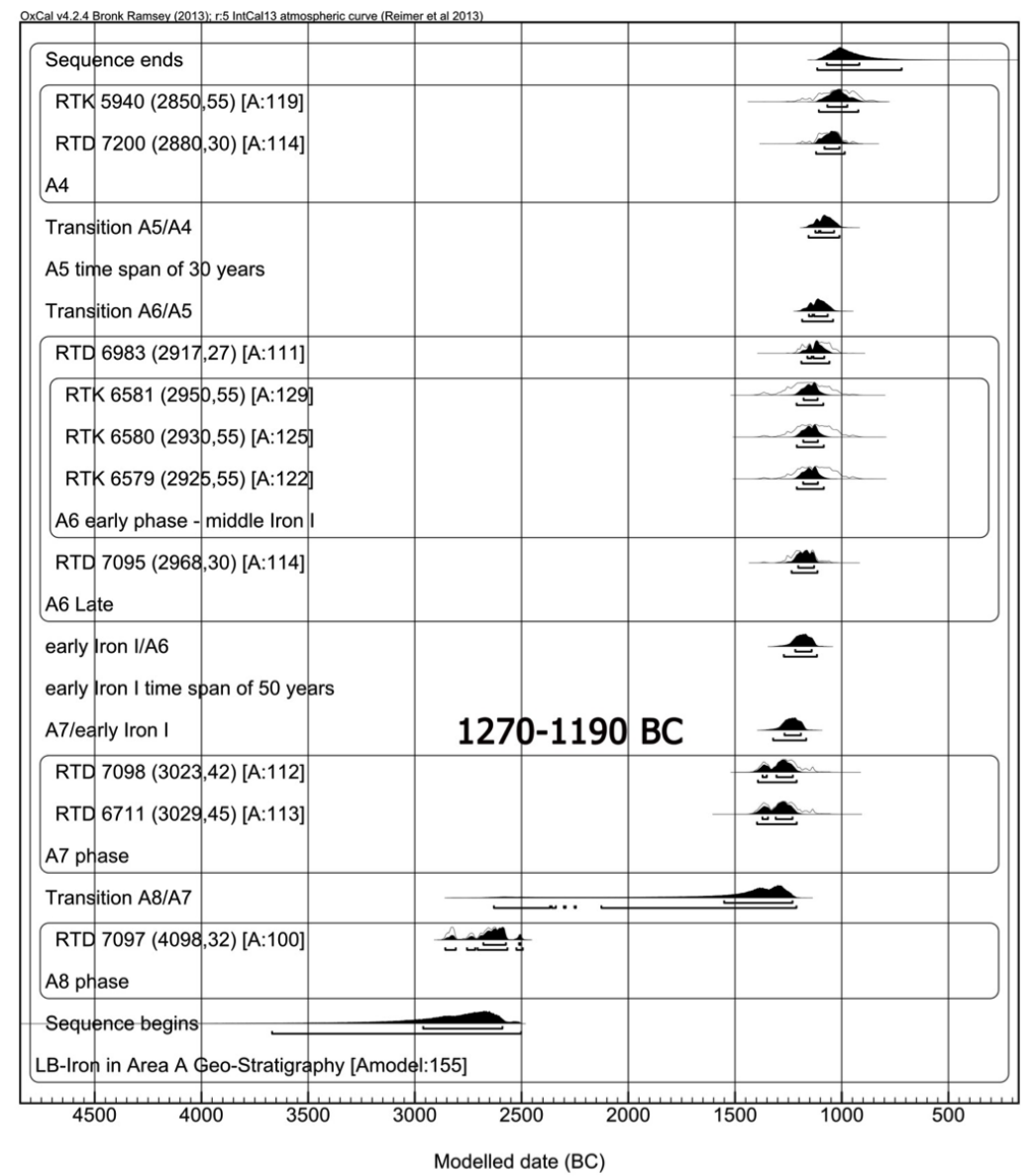

Figure 16 Calibrated and modeled dates from Area A, Localities I-IV in Tell es-Safi/Gath. Dates are arranged in a sequence from the earliest Stratum A7 to the latest Stratum A4, including a gap of $50 \mathrm{yr}$ to represent the early Iron I cultural phase. Dates are presented with their lab number, age before calibration, precision (in parentheses), and their agreement index (in square brackets). The modeled date of the Late Bronze Age (Stratum A7) to Iron Age (the early Iron I gap) transition is between $1270-1190 \mathrm{BC}$ at $1 \sigma$ confidence level.

\section{COMBINED CULTURAL-STRATIGRAPHIC MODEL OF TELL ES-SAFI/GATH}

There are several other ${ }^{14} \mathrm{C}$ dates available from well-defined contexts that can alleviate the weaknesses identified earlier, but these are not physically connected to the Area A sequence. We now test whether or not the incorporation of these dates changes the modeled transition date. The dates from Area P (Stratum 2) and from Locality V in Area A are associated with Late Bronze Age material culture. In Area F, dates of short-lived samples are available that are associated with the early Iron I material culture (Toffolo et al. 2012). The combined cultural-stratigraphic model is described as a sequence from the earliest sample to the latest. The sequence begins with the oldest stratum that is relevant to the transition, Stratum A7 (RTK 7201, 7096, 7098, 6711, 7366) in Area A, and Stratum P2 (RTK 6710, 7182, 7365) in Area P. Both strata contain Late Bronze IIB pottery, and they are both considered as an unordered group of events since they could not be linked stratigraphically (in the OxCal software, this is executed by the command "phase"). After the Late Bronze Age phase, an early Iron Age I phase is included using previously published dates from Area F, Stratum F2 lower 
(only the dates from reliable samples were used: RTK 6141, 6143, 6144). These are dates from short-lived samples found on an occupation surface (Toffolo et al. 2012). These early Iron Age I dates are considered as an unordered group of events since they come from the same surface (executed by the command "phase"). The early Iron I phase (Stratum F2 lower) is followed by a middle Iron I phase from Area A (Stratum A6 in Locality I). The remaining sequence of dates is the same as the one in the geostratigraphic model.

Figure 17 shows the $17{ }^{14} \mathrm{C}$ dates from the three different areas calibrated using OxCal v 4.2.3, based on the IntCal13 curve data (Reimer et al. 2013). The best modeled Late Bronze to Iron Age transition date, between the Late Bronze Age IIB phase (containing Cypriot and Aegean imports) and the early Iron I Age phase (containing Philistine 1 pottery), is between 1310-1250 BC at $1 \sigma$ confidence level. The agreement index of the entire model is $135 \%$.

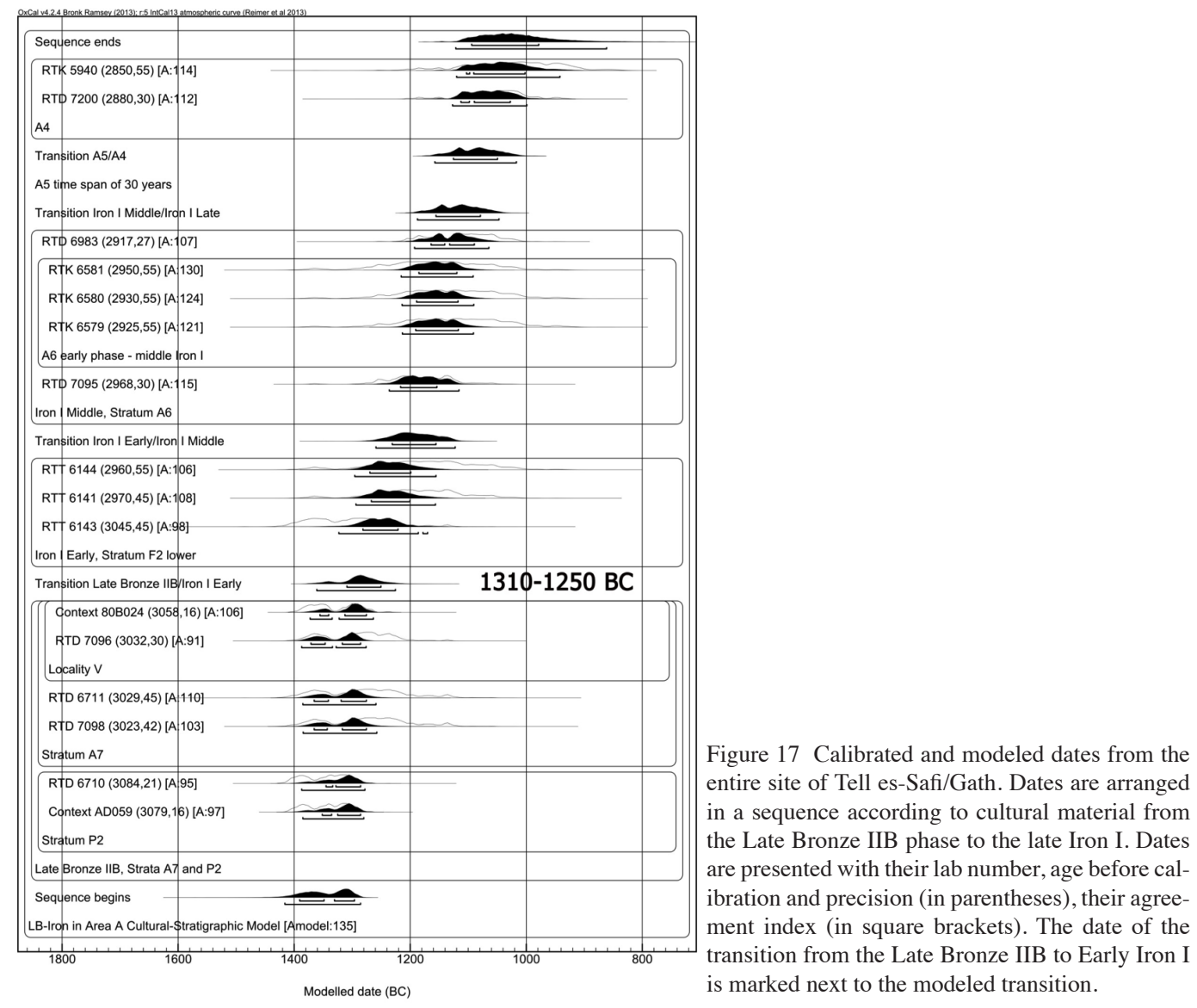

\section{THE ABSOLUTE DATE OF THE LATE BRONZE TO IRON AGE TRANSITION}

Table 2 summarizes the dates of the transitions using the different models. The agreement indices of all the models do not change much (all above 130\%). The different modeled transitions of the Late Bronze to Iron Age are all during the 13th century BC. The cultural transition between the early Iron I to middle Iron I (associated with the cultural change of Philistine 1 to Philistine 2) spans the end of the 13 th century $\mathrm{BC}$ till the first half of the 12 th century $\mathrm{BC}$ at $1 \sigma$ confidence level. 
Table 2 Summary of the transition dates from the different models.

\begin{tabular}{lllll}
\hline Model & $\begin{array}{l}\text { Late Bronze Age to } \\
\text { Iron Age transition }\end{array}$ & $\begin{array}{l}\text { Early Iron I to mid- } \\
\text { dle Iron I transition }\end{array}$ & $\begin{array}{l}\text { Model agree- } \\
\text { ment index }\end{array}$ & Notes \\
\hline Geostratigraphy & $1245-1160 \mathrm{BC}$ & N/A & $155 \%$ & $\begin{array}{l}\text { Early Iron I period is } \\
\text { absent from this model, } \\
\text { and Late Bronze has lim- } \\
\text { ited }{ }^{14} \mathrm{C} \text { representation. }\end{array}$ \\
$\begin{array}{l}\text { Geostratigraphy }+ \\
\text { gap of 50 yr }\end{array}$ & $1270-1190 \mathrm{BC}$ & $1220-1140 \mathrm{BC}$ & $155 \%$ & $\begin{array}{l}\text { Early Iron I period is } \\
\text { simulated as 50 yr, and } \\
\text { the Late Bronze has lim- } \\
\text { ited }{ }^{14} \mathrm{C} \text { representation. }\end{array}$ \\
$\begin{array}{l}\text { Combined cultural- } \\
\text { stratigraphic }\end{array}$ & $1310-1250 \mathrm{BC}$ & $1230-1155 \mathrm{BC}$ & $135 \%$ & $\begin{array}{l}\text { Early Iron I period and } \\
\text { Late Bronze phase are } \\
\text { represented by }{ }^{14} \mathrm{C} \text { from } \\
\text { different areas in the site }\end{array}$ \\
\hline
\end{tabular}

The difference between the three models, presented in Table 2, spans around $70 \mathrm{yr}$ for the date of the Late Bronze to Iron Age transition in Tell es-Safi/Gath. All three models are consistent with the transition being in the 13 th century $\mathrm{BC}$. We also note that as we introduced missing stratigraphic and material culture information into the models in a sequential mode, the transition age became older.

The transition dates of the different models at Tell es-Safi/Gath can be compared to similar studies at Qubur el-Walaydah (Asscher et al. 2015) and Megiddo (Toffolo et al. 2014). At all three sites, the pottery assemblages before and after the transition are contemporaneous, based on relative chronology (in Megiddo and Qubur el-Walaydah the phase that is associated with the initial Philistine appearance in Philistia is Late Bronze III, and in Tell es-Safi/Gath is named early Iron I). Although these assemblages are all considered contemporaneous, their absolute transition dates are different. The Late Bronze IIB and Late Bronze III transition in Qubur el-Walaydah is between 1230-1185 BC at $1 \sigma$ confidence level. The Late Bronze IIB and Late Bronze III transition in Megiddo (general model, see Toffolo et al. 2014 for details) is between 1180-1135 BC at $1 \sigma$ confidence level. It therefore appears that the transition at Megiddo is later than at the other two sites.

The site of Megiddo provides an important insight into the difficulties of dating this transition. At Megiddo, dates from two areas on the tell ( $\mathrm{H}$ and $\mathrm{K}$ ) were incorporated to produce a chronological sequence of the entire site (Toffolo et al. 2014) on the assumption that layers containing the same cultural material are contemporaneous. However, when constructing a chronology for each area separately, the Late Bronze and Iron Age transition date of Area H is between 1125-1070 BC, and Area $\mathrm{K}$ is between $1185-1135 \mathrm{BC}$ at $1 \sigma$ confidence level. The transition dates differ between the two areas within the same site by more than $60 \mathrm{yr}$, and the general model transition date is 1180$1135 \mathrm{BC}$ at $1 \sigma$ confidence level (similar to Area K). Similar to Megiddo, the observed 70-yr timespan between the transition dates derived from the different models at Tell es-Safi/Gath is a result of implementing the assumption that layers containing the same cultural material are contemporaneous in the chronological model. Therefore, the realistic precision that we can obtain for the date of this transition at Tell es-Safi/Gath is around $70 \mathrm{yr}$ and the transition occurs in the 13 th century BC.

\section{THE ABSOLUTE DATE OF THE LATE BRONZE TO IRON AGE TRANSITION AT TELL ES-SAFI/ GATH: HISTORICAL IMPLICATIONS}

In the discussion on the chronology of the Late Bronze to Iron Age transition, three hypotheses 
relate to the Egyptian retreat from the southern coastal Levant and the time of the appearance of the Philistines. The high chronology hypothesis assumes that Philistines entered the region before Ramses III (e.g. Albright 1932; Dothan 1982, 1993; Mazar 2007). The high chronology dates the appearance of Philistine 2 pottery to around the time of Ramses III, whose reign commenced between 1196-1185 BC, based on available ${ }^{14} \mathrm{C}$ dates and by incorporating historical information on reign lengths (Bronk Ramsey et al. 2010).

The middle chronology hypothesis dates the appearance of the Philistines to after the eighth year of Ramses III (the historical date of Ramses III campaign against the Sea Peoples, with whom the Philistines are associated). The date was mainly based on the historical interpretations of the Medinet Habu inscription and Papyrus Harris I (Killebrew 2005:232 n. 111). The middle chronology was recently reaffirmed in Ashkelon (Master et al. 2011) and Qubur el-Walaydah (Asscher et al. 2015), and is consistent with published studies (Mazar 1985; Singer 1985; Stager 1985). The middle chronology hypothesis assumes that the Philistines (associated with Philistine 1 pottery) appeared in the southern coastal plain, at the eighth year of Ramses III (around $1175 \mathrm{BC}$ ), and that after the Egyptian rule ended in the southern Levant, during the time of Ramses IV and VI (around 1130 BC), Philistine 2 appeared (Carmi and Ussishkin 2004; Mazar 2007; Sherratt and Mazar 2013).

The third hypothesis, i.e. the low chronology hypothesis, assumes that the Philistines arrived (associated with Philistine 1 pottery) in the southern Levant after the retreat of the Egyptian reign, at the time of Ramses IV and VI (Ussishkin 1985; Finkelstein 1995, 1998, 2007). This hypothesis dates the appearance of Philistine 1 and Philistine 2 to after Ramses IV and VI based on historical finds within the archaeological record (Krauss 1994; Brandl 2004; Finkelstein 2007; Ussishkin 2007).

The Late Bronze to Iron Age transition in Tell-es-Safi/Gath shows that Philistine 1 pottery appeared during the 13th century BC, in agreement with the high chronology hypothesis. Clearly, the cultural transition in Philistia in the south was prior to the transition in the northern site of Megiddo, as previously suggested (Albright 1932; Mazar 1990, 2007; Killebrew 2005). Archaeological finds date the Egyptian presence in the southern Levant to the 20th Dynasty of Egypt, until the time of Ramses IV and VI (Ussishkin 1985, 2007; Finkelstein 1995, 1998, 2007). This implies that the Philistine culture appeared in certain locations in Philistia perhaps even a century before the Egyptian withdrawal from the region. An early dating of the appearance of the Philistine culture at some sites supports suggestions (e.g. Hitchcock and Maeir 2014) that the appearance of the Philistines and other Sea Peoples was a complex and drawn out process, most likely not associated solely with specific, and chronologically limited, historical events.

\section{CONCLUSIONS}

Fourteen ${ }^{14} \mathrm{C}$ dates from microarchaeologically well-defined contexts form the basis of Bayesian models that incorporate stratigraphic sequence information of the Late Bronze Age to Iron Age transition at Tell es-Safi/Gath. The models all show that the transition and the appearance of Iron Age material culture took place in the 13th century BC. This transition dates the arrival of the Philistines to the southern Levant to the 19th dynasty of Egypt.

\section{ACKNOWLEDGMENTS}

Funding was provided by the Kimmel Center for Archaeological Science and D-REAMS Radiocarbon Dating, Weizmann Institute of Science, and the European Research Council under the European Community's Seventh Framework Programme (FP7/2007-2013)/ERC grant agreement n ${ }^{\circ}$ 229418. We would like to gratefully acknowledge the generous financial help from Mr George Schwartzman. D.C.'s contribution is part of the activities of the Equip de Recerca Arqueologica i 
Arqueomètrica de la Universitat de Barcelona (ERAAUB), Consolidated Group (2014 SGR 845), thanks to the support of the Comissionat per a Universitats i Recerca del DIUE de la Generalitat de Catalunya. We would like to thank Shira Kisos for her help in pottery drawings and photographs, and Brent Davis, Erin McGowan, James Stratford, Jill Katz, and Brianna Flynn for their help in determining the stratigraphy. Finally, we thank the staff and team of the Ackerman Family Bar-Ilan University Expedition at Gath for their dedicated work during and after the excavations.

\section{REFERENCES}

Albright WF. 1932. The Excavation of Tell Beit Mirsim: Volume I: The Pottery of the First Three Campaigns. New Haven: Yale University Press.

Alt A. 1944. Ägyptische Tempel in Palästina und die Landnahme der Philister. Zeitschrift des Deutschen Palästina-Vereins 67:1-20.

Asscher Y, Lehmann G, Rosen SA, Weiner S, Boaretto E. 2015. Absolute dating of the Late Bronze to Iron Age transition and the appearance of Philistine Culture in Qubur el-Walaydah, southern Levant. Radiocarbon 57(1):77-97.

Bietak M. 1993. The Sea Peoples and the end of the Egyptian administration in Canaan. Biblical Archaeology Today, 1990. Proceedings of the Second International Congress on Biblical Archaeology, Jerusalem, June-July 1990. Jerusalem: Israel Exploration Society. p 292-306.

Boaretto E. 2007. Determining the chronology of an archaeological site using radiocarbon: minimizing uncertainty. Israel Journal of Earth Sciences $56: 207-16$

Boaretto E. 2009. Dating materials in good archaeological contexts: the next challenge for radiocarbon analysis. Radiocarbon 51(1):275-81.

Brandl B. 2004. Scarabs and plaques bearing royal names of the early 20th Egyptian Dynasty excavated in Canaan - from Sethnakht to Ramesses IV. In: Bietak M, Czerny E, editors. Scarabs of the Second Millennium BC from Egypt, Nubia, Crete and the Levant, Chronological and Historical Implications. Papers of a Symposium, Vienna, 10th-13th of January 2002. Österreichischen Akademie der Wissenschaften Denkschriften der Gesamtakademie, Band 35: Contributions to the Chronology of the Eastern Mediterranean 8. Vienna: Verlag der ÖsterreichischenAkademie der Wissenschaften. p 57-71.

Bronk Ramsey C. 1995. Radiocarbon calibration and analysis of stratigraphy: the OxCal program. Radiocarbon 37(2):425-30.

Bronk Ramsey C. 2009. Bayesian analysis of radiocarbon dates. Radiocarbon 51(1):337-60.

Bronk Ramsey C, Dee MW, Rowland JM, Higham TFG, Harris SA, Brock F, Quiles A, Wild EM, Marcus ES, Shortland AJ. 2010. Radiocarbon-based chronology for dynastic Egypt. Science 328(5985):1554-7.

Bullock P, Fedoroff N, Jongerius A, Stoops G, Tursina T, Babel U. 1985. Handbook for Soil Thin Section Description. Albrighton: Waine Research Publications.

Carmi I, Ussishkin D. 2004. Ussishkin D, editor. The Renewed Archaeological Excavations at Lachish
(1973-1994). Monograph Series of the Sonia and Marco Nadler Institute of Archaeology. Tel Aviv 22. p 2508-13.

Cline EH. 2014. 1177 BC: The Year Civilization Collapsed. Princeton: Princeton University Press.

Courty MA, Goldberg P, Macphail R. 1989. Soils and Micromorphology in Archaeology. Cambridge: Cambridge University Press.

Dothan M. 1971. Ashdod II-III: The Second and Third Seasons of Excavations 1963, 1965. Atiqot 9-10. Jerusalem: Israel Antiquities Authority.

Dothan T. 1982. The Philistines and Their Material Culture. Jerusalem.

Dothan M. 1993. Ashdod. In: Stern E, editor. The New Encyclopedia of Archaeological Excavations in the Holy Land. Volume 1. Jerusalem: Carta. p 93-102.

Dothan M, Ben-Shlomo D. 2005. Ashdod VI: The Excavations of Areas $H$ and $K$ (1968-1969). Jerusalem: Israel Antiquities Authority Reports 24.

Dothan M, Freedman DN. 1967. Ashdod I: The First Season of Excavations 1962. Atiqot 7. Jerusalem: Israel Antiquities Authority.

Dothan M, Porath Y. 1982. Ashdod IV: Excavation of Area $M$, the Fortifications of the Lower City. Jerusalem: Department of Antiquities and Museums. Atiqot 15.

Dothan M, Porath Y. 1993. Ashdod V: The Fourth-Sixth Seasons of Excavations 1968-1970. Atiqot 23. Jerusalem: Israel Antiquities Authority.

Dothan T, Gitin S, Zukerman A. 2006. The pottery: Canaanite and Philistine traditions and Cypriot and Aegean imports. In: Meehl M, Dothan T, Gitin S, editors. Tel Miqne-Ekron Excavations 1995-1996: Field INE east Slope, Iron Age I (Early Philistine Period). Jerusalem: W.F. Albright Institute of Archaeology. p 71-175.

Elbaum R, Weiner S, Albert R, Elbaum M. 2003. Detection of burning of plant materials in the archaeological record by changes in the refractive indices of siliceous phytoliths. Journal of Archaeological Science 30(2):217-26.

Eliyahu-Behar A, Yahalom-Mack N, Shilstein S, Zukerman A, Shafer-Elliott C, Maeir AM, Boaretto E, Finkelstein I, Weiner S. 2012. Iron and bronze production in Iron Age IIA Philistia: new evidence from Tell es-Safi/Gath, Israel. Journal of Archaeological Science 39(2):255-67.

Finkelstein I. 1995. The date of the settlement of the Philistines in Canaan. Tel Aviv 22(2):213-39.

Finkelstein I. 1998. Philistine chronology: high, middle 
or low? In: Gitin S, Mazar A, Stern E, editors. Mediterranean Peoples in Transition: Thirteenth to Early Tenth Centuries BCE. Jerusalem: Israel Exploration Society. p 140-7.

Finkelstein I. 2007. Is the Philistine paradigm still viable? In: Czerny E, Bietak M, editors. The Synchronisation of Civilisations in the Eastern Mediterranean in the Second Millennium B.C. III. Proceedings of the SCIEM 2000 - 2nd EuroConference Vienna, 28th of May-1st of June 2003. Vienna: Österreichische Akademie der Wissenschaften. p 517-24.

Finkelstein I. 2009. Destructions: Megiddo as a case study. In: Schloen JD, editor. Exploring the Longue Durée. Winona Lake: Eisenbrauns. p 113-26.

Finkelstein I, Piasetzky E. 2010. Radiocarbon dating the Iron Age in the Levant: a Bayesian model for six ceramic phases and six transitions. Antiquity 84(324):374-85.

Finkelstein I, Piasetzky E. 2011. The Iron Age chronology debate: Is the gap narrowing? Near Eastern Archaeology 74(1):50-4.

Friesem D, Boaretto E, Eliyahu-Behar A, Shahack-Gross R. 2011. Degradation of mud brick houses in an arid environment: a geoarchaeological model. Journal of Archaeological Science 38(5):1135-47.

Gur-Arieh S, Boaretto E, Maeir A, Shahack-Gross R. 2012. Formation processes in Philistine hearths from Tell es-Safi/Gath (Israel): an experimental approach. Journal of Field Archaeology 37(2):121-31.

Head HH. 1962. Rutley's Elements of Mineralogy. London: Thomas Murby \& Co. p 152-5.

Hitchcock LA, Maeir MA. 2014. Yo-ho, yo-ho, a seren's life for me! World Archaeology 46(4):624-40.

Hitchcock LA, Horwitz LK, Boaretto E, Maeir AM. 2015. One Philistine's trash is an archaeologist's treasure: feasting at Iron Age I, Tell es-Safi/Gath. Near Eastern Archaeology 78(1):12-25.

Katz O, Cabanes D, Weiner S, Maeir A, Boaretto E, Shahack-Gross R. 2010. Rapid phytolith extraction for on-site analysis of phytolith concentrations and assemblages: an application at Tell es-Safi/Gath. Journal of Archaeological Science 37(7):1557-63.

Killebrew A. 2005. Biblical Peoples and Ethnicity: An Archaeological Study of Egyptians, Canaanites, Philistines, and Early Israel 1300-1100 BCE. Atlanta: Society of Biblical Literature

Killebrew AE, Lehmann G. 2013. The Philistines and Other "Sea Peoples" in Text and Archaeology. Atlanta: Society of Biblical Literature.

Krauss R. 1994. Einwahrscheinlicher Terminus post quemfür das Ende von Lachisch VI. Mitteilungen der Deutschen Orient-Gesellschaft 126:123-30.

Maeir AM, editor. 2012. Tell es-Safi/Gath I: The 1996 2005 Seasons. Wiesbaden: Harrassowitz.

Maeir A, Hitchcock LA, Horwitz LK. 2013. On the constitution and transformation of Philistine identity. Oxford Journal of Archaeology 32(1):1-38.

Manning SW. 2006-2007. Why radiocarbon dating 1200 $\mathrm{BC}$ is difficult: a sidelight on dating the end of the Late Bronze Age and the contrarian contribution.
ScriptaMediterranea 27-28:53-80.

Master DM, Stager LE, Yasur-Landau A. 2011. Chronological observations at the dawn of the Iron Age in Ashkelon. Egypt and the Levant 21:261-80.

Mazar A. 1985. The emergence of the Philistine material culture. Israel Exploration Journal 35:95-107.

Mazar A. 1990. Archaeology of the Land of the Bible 10,000-586 BCE. New York.

Mazar A. 2007. Myc IIIC in the Land of Israel: its distribution, date and significance. In: Czerny E, Bietak $\mathrm{M}$, editors. The Synchronisation of Civilisations in the Eastern Mediterranean in the Second Millennium B.C. III. Proceedings of the SCIEM $2000-2$ nd EuroConference Vienna, 28th of May-1st of June 2003. Vienna: Österreichische Akademie der Wissenschaften. p 571-82.

Namdar D, Zukerman A, Maeir AM, Katz JC, Cabanes D, Trueman C, Shahack-Gross R, Weiner S. 2011. The 9th century BCE destruction layer at Tell es-Safi/Gath, Israel: integrating macro- and microarchaeology. Journal of Archaeological Science 38(12):3471-82.

Olson BR, Placchetti RA, Quartermaine J, Killebrew AE. 2013. The Tel Akko Total Archaeology Project (Akko, Israel): assessing the suitability of multiscale 3D field recording in archaeology. Journal of Field Archaeology 38(3):244-62.

Pearson GW, Stuiver M. 1986. High-precision calibration of the radiocarbon time scale, 500-2500 BC. Radiocarbon 28(2B):839-62.

Rebollo NR, Cohen-Ofri I, Popovitz-Biro R, Bar-Yosef O, Meignen L, Goldberg P, Weiner S, Boaretto E. 2008. Structural characterization of charcoal exposed to high and low $\mathrm{pH}$ : implications for ${ }^{14} \mathrm{C}$ sample preparation and charcoal preservation. $R a$ diocarbon 50(2):289-307.

Regev L, Zukerman A, Hitchcock LA, Maeir AM, Weiner S, Boaretto E. 2010. Iron Age hydraulic plaster from Tell es-Safi/Gath, Israel. Journal of Archaeological Science 37(12):3000-9.

Regev J, Finkelstein I, Adams MJ, Boaretto E. 2014. Wiggle-matched ${ }^{14} \mathrm{C}$ chronology of Early Bronze Megiddo and synchronization of Egyptian and Levantine chronologies. Egypt and the Levant 24:243-66.

Reimer PJ, Bard E, Bayliss A, Beck JW, Blackwell PG, Bronk Ramsey C, Buck CE, Cheng H, Edwards RL, Friedrich M, Grootes PM, Guilderson TP, Haflidason H, Hajdas I, Hatté C, Heaton TJ, Hoffmann DL, Hogg AG, Hughen KA, Kaiser KF, Kromer B, Manning SW, Niu M, Reimer RW, Richards DA, Scott EM, Southon JR, Staff RA, Turney CSM, van der Plicht J. 2013. IntCal13 and Marine13 radiocarbon age calibration curves $0-50,000$ years cal BP. Radiocarbon 55(4):1869-87.

Sharon I, Gilboa A, Jull T, Boaretto E. 2007. Report on the first stage of the Iron Age Dating Project in Israel: supporting a low chronology. Radiocarbon 49(1):1-46.

Sherratt S, Mazar A. 2013. 'Mycenaean IIIC' and related pottery from Beth Shean. In: Killebrew AE, 
Lehmann G, editors. The Philistines and Other 'Sea Peoples' in Text and Archaeology. Society of Biblical Literature Archaeology and Biblical Studies 15. Atlanta: Society of Biblical Literature.

Singer I. 1985. The beginning of Philistine settlement in Canaan and the northern boundary of Philistia. Tel Aviv 12(2):109-22.

Stager LE. 1985. Merneptah, Israel and Sea Peoples: new light on an old relief. Eretz Israel 18:56-65.

Stager LE. 1995. The impact of the Sea Peoples in Canaan (1185-1050 BCE). In: Levy TE, editor. $A r$ chaeology of Society in the Holy Land. London: Leicester University Press. p 332-48.

Stoops G. 2003. Guidelines for Analysis and Description of Soil and Regolith Thin Sections. Madison: Soil Science Society of America.

Toffolo M, Maeir A, Chadwick JR, Boaretto E. 2012. Characterization of contexts for radiocarbon dating: results from the Early Iron Age at Tell es-Safi/Gath, Israel. Radiocarbon 54(3-4):371-90.

Toffolo M, Arie E, Martin M, Boaretto E, Finkelstein I. 2014. The absolute chronology of Megiddo, Israel in the Late Bronze and Iron ages: high-resolution radiocarbon dating. Radiocarbon 56(1):221-44.
Ussishkin D. 1985. Levels VII and VI at Tel Lachish and the end of the Late Bronze Age in Canaan. In: Tubb $\mathrm{JN}$, editor. Palestine in the Bronze and Iron Ages: Papers in Honour of Olga Tufnell. London: Institute of Archaeology. p 213-30.

Ussishkin D. 2007. Lachish and the date of the Philistine settlement in Canaan. In: Czerny E, Bietak M, editors. The Synchronisation of Civilisations in the Eastern Mediterranean in the Second Millennium B.C. III. Proceedings of the SCIEM 2000 - 2nd EuroConference Vienna, 28th of May-1st of June 2003. Vienna: Österreichische Akademie der Wissenschaften. p 601-8.

Weiner S. 2010. Microarchaeology. Beyond the Visible Archaeological Record. Cambridge: Cambridge University Press.

Yasur-Landau A. 2010. The Philistines and Aegean Migration at the End of the Late Bronze Age. Cambridge: Cambridge University Press.

Yizhaq M, Mintz G, Cohen I, Khalaily H, Weiner S, Boaretto E. 2005. Quality controlled radiocarbon dating of bones and charcoal from the Early PrePottery Neolithic B (PPNB) of Motza (Israel). Radiocarbon 47(2):193-206. 